\title{
Tüfekhane-i Âmire’yi Mamur Kılmak: Osmanlı Tüfek İmalatında Avrupalı Uzmanların Rolü
}

Serdal Soyluer*

Thriving the Ottoman Imperial Armory (Tüfekhane-i Amire): The Role of European Experts in Ottoman Small Arms Manufacture

Abstract - This study examines the role of European experts in the production of muskets and rifles in the Tüfekhane-i Amire (the Ottoman Imperial Armory), which was established as the light weapons production center of the Ottoman Empire. This paper aims to detail the first time when the rifle-type weapon in the Ottoman army is being used effectively, where they are manufactured and repaired. Within this context, beginning from the use of the rifle for the first time in the Ottoman army until the fall of the empire, who controls the production of the rifle and how it is carried out, the number of personnel employed in the Ottoman armories -particularly in the Tüfekhane-i Amire-, their nationality and the influence of European experts on the rifle manufacturing process will be under spotlight. Besides, the effects of the European experts employed in the Tüfekhane-i Âmire and the Zeytinburnu Silah Fabrikast (Zeytinburnu Armory) -an extension of the Tüfekhane in the late nineteenth centuryon the Ottoman light weaponry, especially in a period when weapons technology has developed rapidly and weapons of war were industrialized, will be examined.

Keywords: Ottoman Arms Industry, Ottoman Imperial Armory, Zeytinburnu Armory, Rifle, Technology Transfer, European Experts.

\section{Giriş}

\section{Osmanlı Ordusunda Tüfeğin Yaygın Şekilde Kullanılmaya Başlanması ve Osmanlı Tüfek İmalathaneleri}

Osmanlı kaynaklarında ahşap bir kundak üzerine yerleştirilmiş namludan ve namludaki ateşleme tertibatı ile nişangâhtan ibaret olan ateşli el silahlarına tüfenk,

* Muğla Sıtkı Koçman Üniversitesi. 
tüfeng veya tüfek adı verilmektedir. ${ }^{1}$ Tüfek, Osmanlılara muhtemelen ticaret yoluyla ya da Balkan ve Doğu Akdeniz'de Avrupalı hasımlarına karşı yapmış oldukları akın ve savaşlar neticesinde geçmiş olmalıdır. ${ }^{2}$ Osmanlıların, ilkel örnekleri küçük toplara benzeyen ve geri tepme hızı yüzünden sabit bir destek olmaksızın ateşlenemeyen bu küçük ateşli silahları ilk kez ne zaman kullandıklarına dair 1394, 1402, 1421, 1430, 1432, 1440, 1442 ve 1444 gibi muhtelif tarihler öne sürülmektedir. ${ }^{3}$ Feridun Emecen ise bu verilerin zayıf olduğunu, Osmanlıların tüfek cinsi silahı kesin olarak II. Kosova Savaşı'nda (1448) kullandıklarını delilleriyle ortaya koymuştur. ${ }^{4} \mathrm{Bu}$ savaştan sonra İstanbul'un fethi sırasında da kullanılan tüfek, kısa süre zarfında tüm Osmanlı sınır kaleleri ve önemli istihkâmlarına yayılarak, vazgeçilmez bir savunma ve saldırı silahı hâline gelmiştir. ${ }^{5}$ Osmanlılar, fitilli ve tetiksiz ateşleme mekanizmalı tüfekleri on beşinci yüzyıl sonlarında ve on altıncı yüzyıl boyunca geliştirerek, kendilerine özgü bir tüfek türü meydana getirmişlerdir. Taşınması ve etkili kullanımı çağdaşlarına oranla daha kolay olan ve askerî terminolojiye Osmanlı tüfeği olarak geçen bu silahın, Osmanlı ordusunun yanı sıra Yakın ve Uzak Doğu'da da tercih edildiği bilinmektedir. ${ }^{6}$

1 Gabor Ágoston, “Osmanlida Top, Tüfek ve Tabur”, Gábor Ágoston, Osmanlida Ateşli Silahlar ve Askeri Devrim Tartı̧maları, çev. ve yay. haz. Kahraman Şakul (İstanbul: Türkiye İş Bankası Kültür Yayınları, 2017), s. 157; Feridun M. Emecen, "Ateşli Silahlar Çağı: Askeri Dönüşüm ve Osmanlı Ordusu”, Feridun M. Emecen, Osmanlı Klasik Çăğında Savaş (İstanbul: Timaş Yayınları, 2010), s. 33-34.

2 Ágoston, "Osmanlı'da Top, Tüfek ve Tabur”, s. 157; Emecen, "Ateşli Silahlar Çağı”, s. 34.

3 Bu tarihler hakkında bkz. Vernon J. Parry, "İslâm’da Harb Sanatı," çev. Erdoğan Merçil, Salih Özbaran, İstanbul Üniversitesi Edebiyat Fakültesi Tarih Dergisi, 28-29 (1974-1975), s. 203; Mücteba İlgürel, “Osmanlı İmparatorluğu'nda Ateşli Silâhların Yayılışı”, İstanbul Üniversitesi Edebiyat Fakültesi Tarih Dergisi, 32 (1979), s. 301.

4 Emecen, "Ateşli Silahlar Çağı", s. 34.

5 Parry, "İslâm'da Harb Sanatı", s. 203; Emecen, "Ateşli Silahlar Çağı”, s. 35; Ágoston, "Savaş Kazandıran Silahlar: Konstantiniye Kuşatmasından (1453) Mohaç Muharebesi’ne (1526) Osmanlı Ateşli Silahlarının Belirleyiciliği”, Gábor Ágoston, Osmanlida Ateşli Silablar ve Askeri Devrim Tartışmaları, çev. ve yay. haz. Kahraman Şakul (İstanbul: Türkiye İş Bankası Kültür Yayınları, 2017), s. 92-100; Ágoston, “Osmanlı'da Top, Tüfek ve Tabur”, s. 157158; Ágoston, Gábor: Barut, Top ve Tüfek: Osmanlı Imparatorluğu’nun Askeri Gücü ve Silah Sanayisi, çev. Tanju Akad (İstanbul: Kitap Yayınevi, 2006), s. 46.

6 Salih Özbaran, “Asya’da ve Afrika’da Ateşli Silahların ve Askeri Teknolojinin Yayılmasında Osmanlıların Rolü," Salih Özbaran, Yemen'den Basra’ya: Sinırdaki Osmanlı (İstanbul: Kitap Yayınevi, 2004), s. 262-264; Kenneth Chase, Ateşli Silahlar Tarihi, çev. Füsun Tayanç, Tunç Tayanç (İstanbul: Türkiye İş Bankası Kültür Yayınları, 2008) s. 147; Kazuaki Sawai, “Japon Teknolojisine Karşı: 16. Yüzyılda Doğu Asya’da Osmanlı Tüfeğinin Yeri,” Eskiçă̆gdan 
Osmanlılar tüfek ihtiyacını sadece kendi imalatı tüfeklerle karşılamamış, tıpkı ilk zamanlarda yaptıkları gibi satın alma yoluyla veya savaş ganimeti olarak da temin etmişlerdir. Devletin yıkılışına kadar devam eden bu uygulama neticesinde Osmanlı silahlı kuvvetleri envanterindeki tüfekler epey çeşitlilik göstermiştir. Nitekim Osmanlı ordusunda on altıncı yüzyılın başlarından itibaren İspanyol kökenli misket (musket) tüfeklerinin, aynı yüzyılın sonlarından itibaren de yine İspanya menşeli çakmaklı (patilla/miquelet) tüfeklerin yaygın olarak kullanılmaya başlaması bunun en açı delillerinden biridir. ${ }^{7}$

Osmanlıların geliştirdiği tüfeklerin üretimiyle, ganimet olarak ve ithal yolla temin edilen tüfeklerin bakım ve onarımları silahhâne, tüfekhânel tüfenghâne, tüfeng kârhanesi adı verilen atölyelerde yapılmaktaydı. Bu atölyelerin merkezi payitaht İstanbul'daki Tüfekhane-i Âmire'ydi. Evliya Çelebi'ye (1611-1684?) göre, İstanbul'daki en eski ve en büyük tüfek imalathanesi olan Tüfekhane-i Âmire, Unkapanı dışında yer almaktaydı ve büyüklü küçüklü 400 dükkândan ibaretti. ${ }^{8}$ Yine Evliya Çelebi'ye göre İstanbul'da Odunkapısı'nın iç yanında ve

Modernçă̆’a Ordular: Oluşum, Teşkilât ve İslev Sempozyumu (14-16 Mayıs 2007), ed. Feridun M. Emecen (İstanbul: Kitabevi Yayınları, 2008), s. 341-354; Giray Fidan, Kanuni Devrinde Çin'de Osmanlı Tüfeği ve Osmanlilar, Yeditepe Yayınevi, İstanbul 2011.

7 Ágoston, "Osmanlı'da Top, Tüfek ve Tabur", s. 159. Osmanlı ordusunda on sekizinci yüzyıl sonuna kadar yaygın olarak kullanılan tüfek türleri hakkında ayrıntılı bilgi için bkz. Ágoston, Barut, Top ve Tüfek, s. 44-52, 126-131; Ágoston, "Osmanlı'da Top, Tüfek ve Tabur”, s. 157-162; Kenneth Chase, Ateşli Silahlar Tarihi, s. 254; Emecen, "Ateşli Silahlar Çă̆ı”, s. 33-64; Emecen, "Askeri Dönüşüm Çağında Evliya Çelebi ve Ateşli Silahlar," Feridun M. Emecen, Osmanlı Klasik Çă̆ında Savaş (İstanbul: Timaş Yayınları, 2010), s. 87-102.

8 Evliya Çelebi b. Derviş Mehmed Zıllî, Evliya Çelebi Seyahatnâmesi, I, haz. Robert Dankoff, Seyit Ali Kahraman, Yücel Dağlı (İstanbul: Yapı Kredi Yayınları, 2006)s. 303; Ondan naklen Ágoston, Barut, Top ve Tüfek, s. 175 ve Emecen, "Askeri Dönüşüm Çağında Evliya Çelebi”, s. 92. Sarraf Hovhannesyan da (1740-1805), Unkapanı'nda bir tüfekhânenin varlığından bahsetmektedir. Ancak onun tarifindeki tüfekhâne, Evliya Çelebi’nin bahsettiği 400 dükkândan oluşan çarşı niteliğindeki bir yapılar topluluğu değil; Unkapanı'nın biraz ilerisinde, surun önünde, sahilde sadece tek binadan müteşekkil bir yapıdır. Sarkis Sarraf Hovhannesyan, Payitaht İstanbul'un Tarihçesi, çev. Elmon Hançer (İstanbul: Tarih Vakfı Yurt Yayınları, 1997), s. 22. Bu kastedilen yapı Cibalikapı dışında, Fener tabir edilen mevkide bulunan ve 1830'lara kadar Osmanlı Devleti'nin merkez tüfekhânesi görevini üstlenen Tüfekhâne-i Âmire olmalıdır. 1840'ların başında İstanbul'da bulunan İngiliz subay Charles White da İstanbul'daki ilk tüfekhanenin II. Mehmed tarafından Unkapanı kapısı civarında kurulduğunu ve David adlı bir gayrimüslimin ustabaşı olarak tüfekhane çalışanlarının başına getirildiğini belirtmektedir. Charles White, Three Years in Constantinople or, Domestic Manners of The Turks in 1844, II (London: Henry Colburn, 1846), s. 247. 
Divanyolu'nda da devlete ait tüfek imalathaneleri mevcuttu. ${ }^{9}$ On sekizinci yüzyıl sonlarında Nizâm-1 Cedid ıslahatları kapsamında Levent Çiftliği'nde tesis edilen atölye ile daha sonra Dolmabahçe'de inşa edilen tüfekhane, Osmanlı Devleti'nin İstanbul'daki diğer önemli tüfek imalathaneleriydi. ${ }^{10}$

Tüfek imalatı yalnızca İstanbul'la sınırlı değildi. Devletin Şam, Mısır, Cezayir gibi Orta Doğu ve Kuzey Afrika'daki eyaletlerinde, Anadolu ve Rumeli'deki sefer güzergâhlarında bulunan önemli kalelerinde küçük çaplı silah atölyeleri mevcuttu. ${ }^{11}$ Tüfek yapımı, sadece devlete ait silah imalathanelerinde (mîrî karhâne) gerçekleştirilmiyordu. Şahıslara ait imalathanelerde de tüfek imal edilmekteydi. Osmanlı Devleti, her ne kadar bu üretimi engellemeye veya hiç olmazsa kontrol altında tutmaya çalışsa da on altıncı yüzyılın sonlarından itibaren şahıslara ait tüfek imalathaneleri Osmanlı coğrafyasının tamamına hızlı bir şekilde yayıldı. ${ }^{12}$ Hatta öyle ki özel silah imalathane mamulü tüfekler kalite bakımından devlet tüfekhanelerinde imal edilen tüfeklere tercih edilir olmuştu. ${ }^{13}$ Devlet ve özel silah

9 Evliya Çelebi, Evliya Çelebi Seyahatnâmesi, s. 303.; Emecen, "Askeri Dönüşüm Çağında Evliya Çelebi", s. 92.

10 Guillaume Antoine Olivier, Voyage dans l'Empire Othoman, l'Égypte et la Perse, I (Paris: Agasse, 1800), s. 95; Mahmud Râif Efendi ve Nizâmı Cedîd'e Dair Eseri, haz. Kemal Beydilli, İlhan Şahin (Ankara: Türk Tarih Kurumu Yayınları, 2001), s. 81; Stanford J. Shaw, Eski ve Yeni Arasinda Sultan III. Selim Yönetiminde Osmanl İmparatorluğu, çev. Hür Güldü (İstanbul: Kapı Yayınları, 2008), s. 188; Serdal Soyluer, "Osmanlı Silah Sanayiinde Modernleşme Çabaları (1839-1876)“ (doktora tezi), İstanbul Üniversitesi Sosyal Bilimler Enstitüsü, 2013, s. 165; Fatih Yeşil, İhtilâller Çă̆ında Osmanlı Ordusu: Osmanlı İmparatorluğu’nda Sosyo Ekonomik ve Sosyo Politik Değişim Üzerine Bir İnceleme (1793-1826) (İstanbul: Tarih Vakfı Yurt Yayınları, 2016), s. 132-133. Câbî Târihi'nde Levent Çiftliği'ndeki tüfekhaneden şöyle bahsedilmektedir: "Levend Çiftliğinde tüfeng-hâneler ve bir bargir ile yirmi beş tüfeng demiri delünüp ve bir uruşda bir tüfeng çakmağı yapılmasını îcâd...”: Câbî Ömer Efendi: Câbî Târihi, I, haz. Mehmet Ali Beyhan (Ankara: Türk Tarih Kurumu Yayınları, 2003), s. 31. Levent Çiftliği Tüfekhanesi alet edevatının bir kısmını, daha önce Hasköy'deki Humbarahane binasında vücuda getirilen tüfek namlusu delmeye mahsus burgu dolabı çarhları oluşturmaktadır. Wolfgang Müller-Wiener, "15. 19. Yüzyılları Arasında İstanbul'da İmalathane ve Fabrikalar", Osmanlılar ve Batı Teknolojisi: Yeni Araştırmalar Yeni Görüssler, haz. Ekmeleddin İhsanoğlu (İstanbul: İstanbul Üniversitesi Edebiyat Fakültesi Yayınları, 1992), s. 69.

11 Emecen, "Ateşli Silahlar Çă̆ı", s. 40.

12 Halil İnalcık, "Military and Fiscal Transformation in the Ottoman Empire, 1600-1700", Archivum Ottomanicum, VI (1980), s. 293.

13 Gabor Ágoston, bir yeniçerinin 1606 yılına ait hatıralarında anlattıklarına dayanarak, on yedinci yüzyıl başlarında şahıslara ait atölyelerde üretilen tüfeklerin, mîrî tüfek kârhanelerinde 
imalathanelerinde tüfek üretimi kalite tartışmalarının gölgesinde on dokuzuncu yüzyılın ortalarına kadar birlikte sürüp gitti. Çünkü özel silah imalathanelerini tamamıla ortadan kaldırmak Osmanlı Devleti'nin pek de işine gelmiyordu. Devlet seçkinleri bu imalathaneler kapatıldığı takdirde devlet kârhanelerinde Osmanlı ordusuna yeter miktar -ya da kalitede- tüfek imal edilemeyeceğinin farkındaydı. Ancak devlet onlara tamamen serbestiyet tanıyarak tüfek üretiminde kontrolü hepten ele geçirmelerini istemiyor, daha da önemlisi onların on altıncı yüzyıldan beri devletin başına büyük dertler açan isyancılara silah satmalarının önüne geçmek istiyordu. Bu yüzden Osmanlı merkez idaresi kimi zaman ölüm cezası gibi şiddetli yaptırımlarla gözdağı vererek, kimi zaman çok kaliteli tüfek yapanlarını ödüllendirerek taşradaki özel tüfek imalatçılarına karşı bir orta yol politikası sergilemek durumunda kaldı.

On sekizinci yüzyılın sonlarında ve tüm on dokuzuncu yüzyıl boyunca Osmanlı devlet seçkinlerinin tüfek imalatında gözettiği temel husus, dışa bağımlı olmaksızın ordunun ihtiyacı olan silahı mîrî tüfek karhânelerinde üretebilmekti. Ucuz, kaliteli ve yeterli ham madde temininde yaşanan sıkıntılar, bunların imalat sürecinde verimli bir şekilde kullanılamamasından ötürü üretim maliyetinin gereksiz şekilde artması gibi nedenlerle yerli tüfek imalatı Avrupa'dan ithal edilen muadiline göre çok daha pahalıya mâl oluyordu. Üstelik kalite bakımından ithal tüfeğin çok gerisindeydi. Yüksek maliyeti ve kalitesizliğine rağmen yerli tüfek imalat1, bir gün düzelir umuduyla devlet seçkinlerince hep desteklendi. Silah temininde Avrupa'ya bağımlı olmaktan kurtulmak için, onun teknolojisine bel bağlayarak yerli tüfek sanayi tesis edilmeye çalışıldı.

Tüfeğin Osmanlı ordusunda ilk kez kullanılmaya başladığı devirden devletin yıkılışına kadarki süreçte Osmanlı tüfekhanelerinde özellikle Tüfekhane-i Âmire'de tüfek imalatında devletin gözettiği hususların neler olduğuna, imalatın kimlerin denetiminde ve nasıl yapıldığına, niçin yabancı uzman istihdam

imal edilen tüfeklere göre daha kaliteli olduğundan bahsetmektedir. Ágoston, Barut, Top ve Tüfek, s. 128-129. Aynı savı İsmail Hakkı Uzunçarşılı, Kavanin-i Yeniçeriyan’ı mehaz göstererek desteklemektedir. İ. Hakkı Uzunçarşılı, Osmanlı Devleti Teşkilâtından Kapukulu Ocaklar, I (Ankara: Türk Tarih Kurumu Yayınları, 1988), s. 366; Kavanin-i Yeniçeriyan (Yeniçeri Kanunları), haz. Tayfun Toroser (İstanbul: Türkiye İş Bankası Kültür Yayınları, 2011), s. 136. Yine aynı yeniçeriye göre devlete bağlı işletmelerdeki tüfek ustaları, devletten düzenli olarak maaş aldıkları halde iş yavaşlatmışlar, disiplinsiz ve umarsızca hareket ederek tüfek üretimini neredeyse durma noktasına getirmişlerdi. Ágoston, Barut, Top ve Tüfek, s. 128-129; Gani Özden, "Osmanlı İmparatorluğu Silahlı Kuvvetlerinin Harp Sanayii Tesisleri," Askeri Tarih Bülteni, 22 (Şubat 1987), s. 63. 
edildiğine, istihdam edilen personel sayısına, uyruğuna ve yabancı uzmanların imalat sürecine etkilerine dair bugüne kadar müstakil bir çalışma yapılmamıştır. ${ }^{14}$ $\mathrm{Bu}$ çalışmanın amacı, Osmanlı arşiv vesikaları, devrin yerli ve yabancı görgü tanıklarının kaleme aldıkları hususi tarih, hatıra, seyahatname, rapor gibi eserlerden yararlanarak devletin merkez tüfek imalathanesi konumundaki Tüfekhane-i Âmire ile onun on dokuzuncu yüzyıl ortalarından itibaren uzantısını teşkil eden Zeytinburnu Silah Fabrikası'nda görev yapan yabancı uzmanların, özellikle silah teknolojilerinin hızla geliştiği on dokuzuncu yüzyıl ve yirminci yüzyıl başlarında Osmanlı hafif silah imalatına katkılarını irdelemektir.

\section{Cemaat-i Tüfengciyân'dan Zeytinburnu Silah Fabrikası'na Osmanlı Hafif Silah Üretiminde Yabancı Uzmanlar}

Osmanlı Devleti'nde tüfek imal ve tamir eden ustalara dair ilk bilgiler II. Bayezid (saltanatı 1481-1512) devrine ait bir in'amât defterinde yer almaktadır. $\mathrm{Bu}$ defterde 1505 yılında kapı ağası tarafından hizmete alınan Gorda adlı bir Hıristiyan'dan tüfekçi olarak bahsedilmektedir. ${ }^{15}$ Söz konusu defterden yirmi yıl sonrasına ait 1526 tarihli ehl-i hıref defterinde tüfek ustası Gorda ve maiyetinde çalışan dokuz tüfekçi, cemaat-i tüfengciyân adı verilen bir meslek grubunu oluşturacak sayıya ulaşmışlardır. Bu tüfekçilerden Gorda’nın kardeşi Gregor ile sonradan Müslüman olan Rus uyruklu Hüdâdad ve Ferhad, II. Bayezid zamanında hizmete alınmışlardır. Kanuni (saltanatı 1520-1566) döneminde adları geçen dörtlüye Musa, Simon veled-i İsak, İsak, David, Mordehay adlarında beş Yahudi ile İvan adında bir Rus tüfek ustası katılmıştır. ${ }^{16} \mathrm{Bu}$ ustaların hafif Osmanlı tüfeğinin geliştirilmesine katkıları muhakkaktır. Aynı zamanda Osmanlı ordusunun on altıncı yüzyılın başlarında tanıştı̆̆ İspanya menşe'li misket (musket) tüfeklerinin imali ve tamiri hususlarında maharet gösterdikleri ve bu tekniği usta-çırak ilişkisi içerisinde sonraki nesil ustalara aktardıkları da doğrudur. Ancak Osmanlı hafif silah endüstrisinin kuruluş ve gelişimini tamamen Gorda ve ekibine mâl

14 Osmanlı silah sanayisine dair bugüne kadar yurtiçi ve yurt dışında yapılan çalışmalar genelde Osmanlı ağır silah ve barut endüstrisi üzerine yoğunlaşmıştır. Osmanlı hafif silah endüstrisine dair yapılan akademik çalışmalar, bu silahların imalat sürecini kurum bazında değil, daha çok üretilen silahın türü ve miktarı üzerinden irdeleyen türde eserlerdir.

15 Hicrî 909-929 Yillarına Ait İn'amat Defteri, İstanbul Büyükşehir Belediyesi Atatürk Kitaplığı, Muallim Cevdet Yazmaları, O.71, vr. 51b; Emecen, "Ateşli Silahlar Çağı”, s. 40.

16 İsmail Hakkı Uzunçarşılı, “Osmanlı Sarayı'nda Ehl-i Hıref (Sanatkârlar) Defterleri,” Belgeler, XI/15 (1986), s. 51; Emecen, "Ateşli Silahlar Çağı”, s. 40. 
etmek yanlış olacaktır. Zirâ Fatih Sultan Mehmed'in (saltanatı 1444-1446, 1451 1481) saltanatının son yıllarında ve II. Bayezid'in saltanatının ilk yıllarında tüfeğin hafifletilmesi ve etkin kullanımına yönelik yerli tüfek ustaları tarafından çalışmalar yapıldığı bilinmektedir. ${ }^{17}$ Ancak bunları ayrıntılı bir biçimde ortaya koyacak verilere henüz ulaşılamamıştır.

Tespit edilebilen usta statüsündeki bu ilk tüfekçi zanaatkâr grubunun tamamen yabancı uyruklulardan meydana gelmiş olması dikkat çekebilir. Oysa bu, Osmanlı Devleti için yadırganacak bir husus değildir. Bazı tarihçilerin İslâmî tutuculuk ithamlarının aksine Osmanlı Devleti, yeni fikir ve teknolojilere daima açı olmuştur. ${ }^{18}$ Yeni fikir ve teknolojilerin Osmanlı Devleti'ne aktarımı ise uzman ve zanaatkârlar yoluyla gerçekleşmiştir. Osmanlı Devleti de tıpkı tarihte güç bularak büyüyen devletlerin hepsinde olduğu gibi, on beşinci ve on altıncı yüzylllarda her türden mesleki bilgi ve beceriye sahip insanlar için bir cazibe merkezi konumundadır. Üstelik bırakın başka bir dine mensup olmayı, kendi mezhebinden olmayanlara bile tahammülün olmadığı bir çağın yaşandığı Avrupaya nazaran, gayrimüslimlere gösterdiği hoşgörüsü, refah seviyesinin yüksekliği ve meritokratik yapısı Osmanlı Devleti'nin cazibesini daha da arttırmıştır. ${ }^{19}$ Ayrıca Avrupa'daki bazı hükümdarların sırf Osmanlı Devleti'nin desteğini almak ve onunla iyi ilişkiler kurmak maksadıyla zaman zaman askerî uzmanlarını İstanbul'a gönderdiği olmuştur. Bu gibi sebeplerle söz konusu yüzyıllarda İstanbul'a çok yoğun bir yabancı uzman ve zanaatkâr akınının yaşandığı görülmektedir. Yabancı uzmanların gönüllü istihdamının yanı sıra savaş ve akınlarda ele geçirilen teknisyenler, mesleki becerileri doğrultusunda zorunlu olarak Osmanlı hizmetinde çalıştırılmışır. Bunun dışında Osmanlı idarecileri İstanbul'u, siyasetin merkezi kılmanın yanında ekonominin ve silah endüstrisinin de merkezi hâline getirmek için yabancı uzman ve zanaatkârları zorunlu göç metoduyla İstanbul'a getirterek burada iskâna tâbi tutmuşlardır. ${ }^{20}$

17 Bu konuda ayrıntılı bilgi için bkz. Emecen, "Ateşli Silahlar Çağı”, s. 35-40.

18 Rhoads Murphey, "Osmanlıların Batı Teknolojisini Benimsemedeki Tutumları: Efrenci Teknisyenlerin Sivil ve Askerî Uygulamalardaki Rolü,” Osmanlılar ve Batı Teknolojisi: Yeni Araştırmalar Yeni Görüşler, haz. Ekmeleddin İhsanoğlu (İstanbul: İstanbul Üniversitesi Edebiyat Fakültesi Yayınları, 1992), s. 7-8, 17.

19 Ágoston, Barut, Top ve Tüfek, s. 68-69. Murphey, "Osmanlıların Batı Teknolojisini Benimsemedeki Tutumları", s. 9-10.

20 Ágoston, Barut, Top ve Tüfek, s. 69-71. 
Yabancı uzman ve zanaatkârların Osmanlı Devleti hizmetine giriş biçimlerini bu şekilde açıkladıktan sonra istihdamlarının hangi alanlarda yoğunlaşığına değinmek yerinde olacaktır. Uzman istihdamının özellikle Tophane-i Âmire ve Tersâne-i Âmire'de yoğunlaştığı görülür. Gerçekten de yabancı uzmanların, özellikle İberya Yarımadası'ndan gelen Yahudilerin top dökümü ve gemi yapım tekniğinde Osmanlı'ya katkıları inkâr edilemez. ${ }^{21}$ Ancak bu katkı, Avrupa merkezci tarihçilerin Osmanlı Devleti'nin yükselişinde yabancı teknisyenlerin önemini olduğundan fazla göstermek ve Osmanlılar’ın Batı teknolojisine bağımlılıklarını ispatlamak için öne sürdükleri abartılı katkı söylemlerinin aksine hiçbir zaman tek başına yeterli olmamıştır. ${ }^{22}$ Osmanlı'yı on beş, on altı ve on yedinci yüzyıllarda kullandığı araç gereçlerin mükemmelliği ve nispeten yeterliliği bakımından hasımlarına üstün kılan etmen, egemen olduğu topraklardaki zengin yer altı ve yer üstü kaynaklarından elde edilen kaliteli malzemeyi, yine bu toprakların farklı unsurlarından oluşan meslek erbabının tecrübeleriyle, yabancı uzmanların teknik bilgilerini birleştirerek, düzgün bir şekilde işleyebilme becerisidir.

On sekizinci yüzyılda Osmanlı Devleti'nde yabancı uzman istihdam politikasının değiştiği görülür. Avusturya yenilgisinin ardından imzalanan Osmanlı Devleti'nin ilk büyük çaplı toprak kaybını yaşadığı Karlofça Antlaşması, devlet seçkinlerini kötü gidişe son verme konusunda daha köklü reformlar yapmaya sevk etmiştir. Osmanlı Devleti, ilk defa Batı’nın askerî disiplin ve mühendislik bakımından kendisinden üstün olduğunu kabul etmiştir. Düşmana mukavemet göstermenin yolunun onun sahip olduğu askerî ve teknik beceriyi edinmekten geçtiği (bi'l-misl mukabele) göz önünde bulundurularak ağır silah ve denizcilik endüstrileri dışında ilk kez başka bir alanda, teknik askerî sınıfların eğitiminde Avrupalı uzman istihdamına başvurulmuştur. Ancak geçmiş yüzyıllardan farklı olarak bu kez Osmanlı Devleti istenen ve tercih eden değil, daha çok isteyen ve geleni kabul eden taraf olacaktır. On sekizinci yüzyılda Osmanlı Devleti'nde görev yapan Avrupalı uzmanların çoğu, geçimsizlikleri nedeniyle kendi devleti veya hizmet ettiği devletin idarecileriyle anlaşamayarak iltica etmek durumunda kalmış maceraperest ruhlu subaylardır. Bunların yanında yine aynı yüzyılda Avrupalı devletler, özellikle Fransa, Osmanlı devlet ve ordu teşkilâtı içinde söz sahibi olacak bir yetkili bulundurmak, istihbarat toplamak, devletler arasındaki

21 Nicolas de Nicolay, Mubteşem Süleyman’ın İmparatorluğunda, ed. Marie-Christine GomezGéraud, Stefanos Yerasimos, çev. Şirin Tekeli, Menekşe Tokay (İstanbul: Kitap Yayınevi, 2014), s. 286.

22 Ágoston, Barut, Top ve Tüfek, s. 72. 
ekonomik ilişkileri daha da geliştirmek maksadıyla Osmanlı Devleti’ne uzman göndermişlerdir. Söz konusu yüzyılda Osmanlı Devleti'nde istihdam edilen Avrupalı uzmanların en bilinenleri Claude-Aleksandre Comte de Bonneval, nam-1 diğer Humbaracı Ahmed Paşa (görev süresi 1731-1747) ve Baron de Tott'tur (görev süresi 1770-1776). ${ }^{23}$ Her ikisi de Osmanlı Devleti'nce kabul görülüşleri ve başarılı sayılmaları bakımından kendilerinden sonra iş bulmak maksadıyla Avrupa'dan gelecek meslektaşlarına ve Osmanlı Devleti üzerinde nüfuz kazanmaya çalışan Avrupa devletlerine örnek teşkil etmişlerdir. ${ }^{24}$

Avrupa'dan gelen uzman ve teknisyenlerin danışmanlığında on sekizinci yüzyılın sonuna kadar teknik askerî sınıfların eğitilmesi, kara ve deniz istihkâmlarının güçlendirilmesi ve yenilenmesi, topçu birlikleri ve istihkâmlar için yeni toplar dökülmesi ve donanma için yeni gemiler inşasına devam edildi. Uzmanların katkılarıyla gerçekleştirilmeye çalışılan ordu ve donanma ıslahatlarının neticeleri, yüzyıl boyunca özellikle Avusturya ve Rusya ile yapılan savaşlardaki mağlubiyetlerde gözler önüne serildi. Çünkü bu devrin askerî reformları, yenileşmenin ön koşulu olan yeterli bilgi birikimi ve ekonomik kalkınma sağlanmadan reformist devlet adamlarının kişisel gayret ve ön görüleriyle gerçekleştirilmeye çalışılmıştı. III. Selim (saltanatı 1789-1807) döneminde ise başlatılan yeniden yapılanma programı devlet politikası hâlini aldı. Daha köklü ve müspet neticeli sslahatlar için müstakil bir kaynak ayrılmış, hangi sahalarda sslahat yapılacağına dair ayrıntılı raporlar hazırlanmış ve bu maksatla Avrupa'ya daimî statüde elçiler gönderilmiştir. Nizâm-1 Cedîd sslahatları kapsamında teknik bilginin aktarımının olmazsa olmazı yabancı uzman istihdamı da belirli bir program dâhilinde yapıldı. Bu tarihten sonra yeni oluşturulan Nizâm-1 Cedîd birliklerine Avrupa tarzında eğitim vermek için eskisinden çok daha fazla sayıda talim subayı getirtildi. Islahat programının daha

23 Humbaracı Ahmed Paşa’nın Osmanlı serüveni hakkında son zamanlarda yapılmış güzel bir monografi için bkz. Uğur Demir, Osmanlı Hizmetinde Bir Mühtedi: Humbaracı Ahmed Paşa (İstanbul: Yeditepe Yayınevi, 2016). Baron de Tott, Fransa’ya döndükten sonra yayınlamış olduğu hatıralarında Osmanlı Devleti ve Müslümanlara dair gerçeği yansıtmayan ön yargılı ve son derece mübalağalı anlatımlara yer vermiştir. Avrupa'da Osmanlı Devleti ve Müslümanlar aleyhine büyük bir kamuoyu oluşmasında son derece etkin bir propaganda aracı olarak kullanılan ve oldukça rağbet gören Baron de Tott'un hatıralarındaki yalan ve abartıları çürüten ve onun Osmanlı reformlarındaki etkinliğinin derecesini delilleriyle ortaya koyan bir çalışma için bkz. Virginia Aksan, "Breaking the Spell of the Baron de Tott: Reframing the Question of Military Reform in the Ottoman Empire, 1760-1830," The International History Review, 24 (2002), s. 253-277.

24 Fatih Yeşil, "Kara Kuvvetlerinde Avrupalı Danışmanlar”, Osmanlı Askerî Tarihi: Kara, Deniz ve Hava Kuvvetleri, 1792-1918, ed. Gültekin Yıldız (İstanbul: Timaş Yayınları, 2013), s. 81. 
sağlıklı bir şekilde yürütülebilmesi maksadıyla birçok teknik kitabın Osmanlıca'ya çevrilmesine ve çevrilen bu kitapların Mühendishane ve Üsküdar'daki matbaalarda basılarak çoğaltılmasına başlandı. ${ }^{25}$ Sadece ağır silah ve gemi endüstrisinde değil, diğer sanayi dallarında da Avrupa standartlarını yakalamak ve mühimmat temininde dışa bağımlılığı mümkün olduğunca azaltmak gayesiyle imalathanelerde düzenlemeler yapıldı ve buralarda istihdam edilmek üzere Avrupa’dan çok sayıda uzman ve teknisyen getirtildi. Bundan hafif silah endüstrisi de olumlu yönde etkilendi. Levent Çiftliği'ndeki Nizâm-1 Cedîd neferlerine ait kışlada Avrupa ordularında kullanılmakta olan çakmaklı ve süngülü tüfeklerden imal etmek üzere modern bir tüfekhane inşa edildi. Bu tesisin tasarım ve idaresi İspanyol mühendis Miguel de Ulloa'ya verildi. ${ }^{26}$ Onun istediklerini kısa zamanda yerine getirebilecek düzeyde yerli usta bulunamadığından, Fransa'dan top ve gülle dökecek, tüfek ve tüfek çakmağı yapabilecek 13 teknisyen talep edildi. Ancak Fransız Hükümeti 1796 yılında sayıları 70’i aşkın bir uzman heyeti gönderdi. ${ }^{27}$ Çoğunun işe yaramaz nitelikte olduğuna kanaat getirilen bu güruhun içerisinden yetenekli 7 tüfekçi ustası ve bir amele grubu seçilerek, herhangi bir alanda istihdam edilmeyenleri Fransa’ya gönderildi. ${ }^{28}$ Fransız usta ve ameleler Fransa'dan beraberlerinde getirdikleri alet-edevatla tüfek imalatına giriştiler. ${ }^{29}$ Üretilen tüfeklerin modeli de

25 Mühendishane matbaasının kuruluşu ve burada basılan kitapların listesi için bkz. Kemal Beydilli, Türk Bilim ve Matbaacılık Tarihinde Mühendishâne Mühendishâne Matbaası ve Kütüphânesi (1776-1826) (İstanbul: Eren Yayınc1lık, 1995); aynı yazar Mühendishâne ve Üsküdar Matbaalarında Basılan Kitapların Listesi ve Bir Katalog (İstanbul: Eren Yayıncılık, 1997).

26 Olivier, Voyage dans l'Empire Othoman, I, s. 95; Shaw, Eski ve Yeni Arasinda Sultan III. Selim, s. 188; Yeşil, İhtilâller Çăğnda Osmanlı Ordusu, s. 133.

27 Fransız elçi Aubert-Du Bayet'nin aracılı̆̆ıyla getirtilen top dökücü, arabacı, humbaracı, marangoz, tüfekçi gibi meslek gruplarından oluşan kalabalık heyet hakkında bkz. Başbakanlık Osmanlı Arşivi (BOA), Hatt-ı Hümâyûn Tasnifi (HAT), 8793, 20 R 1211 (23 Ekim 1796); BOA, HAT, 1728, 20 B 1211 (21 Ocak 1797) Bu belge, Fatih Yeşil tarafından İhtilâller Çă̆ında Osmanlı Ordusu adlı eserde kullanılmıştır; Antoine Juchereau de SaintDenys, Révolutions de Constantinople en 1807 et 1808, II (Paris: Brissot-Thivars, 1819), s. 1213; Gültekin Yıldız, Neferin Adı Yok: Zorunlu Askerliğe Geçiş Sürecinde Osmanlı Devleti’nde Siyaset, Ordu ve Toplum (1826-1839) (İstanbul: Kitabevi Yayınları, 2009), s. 402-403; Yeşil, İhtilâller Çăğnda Osmanlı Ordusu, s. 126.

28 Hasköy Dökümhanesi ve Tophane-i Âmire'deki faaliyetler için işe yarayacak olanları da ayrıldıktan sonra, geriye kalanların Fransa'ya gönderilmesine karar verildi. BOA, HAT, 1728, 22 B 1211 (21 Ocak 1797).

29 BOA, HAT, 8970, 8 L 1211 (6 Nisan 1797). Bu belge, Fatih Yeşil tarafindan İhtilâller Çă̆ında Osmanlı Ordusu adlı eserde kullanılmıştır. 
belirlenmişti. Nizâm-1 Cedîd askerlerine Fransız piyade talimi yaptırıldığından yeni ordunun tüfeği de Fransız askerinin kullanmakta olduğu namlusuna gerektiğinde süngü takılabilen çakmaklı misket tüfekleriyle birebir aynı olmalıyd $1 .{ }^{30} \mathrm{Bu}$ maksatla Fransız Hükümeti, süngüleri namlularına takılmış vaziyette bir miktar çakmaklı tüfeği İstanbul'a göndermişti. ${ }^{31}$

İspanyol asıllı bir genel direktörün idaresinde çalışan Fransız usta ve amelelerle, çoğunluğu Osmanlı gayrimüslimlerinden oluşan personele sahip bu atölyede gerçekleştirilmek istenen başka bir hedef daha vardı. O da imalathanedeki Müslüman personel sayısını arttırarak Avrupa işi tüfek imalinin Müslümanlar tarafından gerçekleştirilmesini sağlamaktı. ${ }^{32} \mathrm{Bu}$ maksatla yeteneklerine güvenilen Osmanlı tüfek ustalarından bir kısmı, dört beş ayda Felemenk-kârî tüfek imalini öğrenmek üzere Fransa’dan gelen usta ve amelelerle birlikte 1797 yılından itibaren Levent Çiftliği Tüfekhanesi'nde çalışmaya başladılar. ${ }^{33}$ Her ne kadar bu modern tüfekhanede üretilen tüfekler, sayı bakımından Nizâm-1 Cedîd ordusunun ihtiyacını kısa sürede karşılamaya yetecek kadar olmasa da kaliteleri Osmanlı Devleti'nin merkez tüfek imalathanesi konumundaki Tüfekhane-i Âmire mamulü tüfekleri gölgede bırakmıştı. Ancak 1807 yılında meydana gelen Kabakçı Mustafa İsyanı ve arkasından 1808 Kasımında vuku' bulan Alemdar Vak'ası, silah manifaktüründe büyük emeklerle elde edilen bu başarıya sekte vurdu. Özellikle Alemdar Vak'ası sırasında Levent Çiftliği'ndeki kışla büyük oranda tahrip edildi. Tahribattan yerleşkede bulunan tüfek imalathanesi de nasibini aldı. ${ }^{34}$ Burada on yılı aşkın süredir modern tüfek imaliyle meşgul olan ustalar, II. Mahmud'un emriyle (saltanatı 1808-1839) Cibalikapı'daki Tüfekhane-i Âmire'ye nakledilerek Felemenk-kârî tüfek imalatını burada sürdürdüler.

Tüfekhane-i Âmire'nin kaderi, iki meş'um isyan neticesinde müspet yönde değişmişti. Dolmabahçe'deki yeni Tüfekhane-i Âmire’nin faaliyete geçtiği 1833

30 Nizâm-1 Cedîd ordusu neferlerine 1755 tarihli Fransız piyade talimi yaptırılması kararlaştırılmıştı. Fatih Yeşil, "Nizâm-1 Cedîd Ordusunda Tâlim ve Terbiye (1790-1807)," İstanbul Üniversitesi Edebiyat Fakültesi Tarih Dergisi, 52/2 (2010), s. 45-47; James Dallaway, Constantinople Ancient and Modern (London: Cadell \& Davies, 1797), s. 43.

31 Saint-Denys, Révolutions de Constantinople, II, s. 20.

32 Yeşil, İhtilâller Çăğnda Osmanlı Ordusu, s. 126.

33 BOA, HAT, 8970, 8 L 1211 (6 Nisan 1797).

34 Saint-Denys, Révolutions de Constantinople, II, s. 140, 256; John Cam Hobhouse, A Journey Through Albania and Other Provinces of Turkey in Europe and Asia, to Constantinople During the Years 1809 and 1810, II (London: Cawthorn, 1813), s. 1046; Charles MacFarlane, Constantinople in 1828, II (London: Saunders and Otley, 1829), s. 64-70, 104. 
yılına kadar burada yoğun bir tüfek ve süngü imal faaliyetinden söz etmek mümkündür. Nitekim 1832 yılında burayı ziyaret eden iki Amerikalı David Porter ve Robert Walsh, Ermeni ustabaşı Bağdasar'ın idaresindeki 500 kişilik ekibin yoğun bir şekilde tüfek ve süngü imaliyle meşgul olduğundan bahsetmektedirler. ${ }^{35}$ Hatta Bağdasar, geliştirdiği küçük buhar makinesi sayesinde tüfek süngüsü yapımında makineleşmeyi başararak, ${ }^{36}$ Osmanlı sanayisinde geleneksel teknolojiden yeni teknolojiye geçişin başarılı örneklerinden birini vermiş oldu. ${ }^{37}$ Tecrübeli ustalar, onların yetiştirdikleri kalfa ve çıraklar, bilhassa Yeniçeri Ocağı'nın kaldırrlışından sonra hafif silah imalatında Tüfekhane-i Âmire'nin tekelleşmesi için II. Mahmud'un emriyle Rumeli'nin tüfek yapımıyla şöhret bulmuş Ohri, Prizren, Üsküp ve Kalkandelen gibi kazalarından getirtilen tüfekçi ustaları sayesinde, Cibalikapı'daki Tüfekhane-i Âmire'de nitelikli personel sayısı arttı. ${ }^{38}$ Çalışan sayısının artmasına bağlı olarak ilave edilen tezgâh ve tornalarla birlikte imalat geçmişe oranla ivme kazanırken fiziki açıdan büyük bir sıkışıklık yaşandı. Seri imalat için yeterli genişlikten yoksun bu tesisi rahatlatmak ve tüfek tornaları ile tezgâhlarını işletmek maksadıyla bu alanda dönemin paradigma devleti İngiltere'den getirtilmesi planlanan buhar makine ve kazanlarının yerleştirilebileceği daha büyük bir tesis oluşturmak üzere harekete geçildi.

35 Robert Walsh, A Residence at Constantinople, II (London: Frederick Westley and A. H. Davis, 1836), s. 431. David Porter, Constantinople and Its Environs, I (New York: Harper \& Brothers, 1835), s. 120-121.

36 Takvim-i Vekayi, No: 21, 7 Za 1247, s. 2; Adnan Giz, “Türkiye'de İlk Buhar Makineleri,” İstanbul Sanayi Odası Dergisi, 57 (Kasım 1970), s. 7; Yavuz Cezar, "19. Yüzyılda Osmanlı Devleti'nde Yeni Teknoloji Uygulama ve Sınaî Tesis Kurma Çabalarından Örnekler," Dünü ve Bugünüyle Toplum ve Ekonomi, 1 (1991), s. 169; İlhan Tekeli, Selim İlkin, "The Public Works Program and The Development of Technology in the Ottoman Empire in the Second Half of the Nineteenth Century," Turcica, 28 (1996), s. 205.

37 Buhar teknolojisinden yararlanma ilk defa madencilik sektöründe gerçekleşmişti. Madenlerde biriken suyu boşaltmak maksadıyla İngiltere'de buhar gücüyle çalışan pompalar yapılmıştı. Isaac Asimov, Bilim ve Buluşlar Tarihi, çev. Elif Topçugil (İstanbul: İmge Kitapevi, 2006), s. 177. Osmanlı Devleti'nde buhar teknolojilerinden ilk istifade girişimleri tespit edilebildiği kadarıyla 1797-1805 yıllarında Tersane-i Âmire'de yeni inşa edilen kuru havuza biriken suları boşaltmak için buhar gücüyle çalışacak bir pompanın konulması tartışmaları sırasında gündeme gelmişti. Bkz. Tuncay Zorlu, Osmanlı ve Modernleşme: III. Selim Dönemi Osmanlı Denizciliği (İstanbul: Timaş Yayınları, 2014), s. 90-95, 118.

38 Yıldız, Neferin Adı Yok, s. 438-440; Soyluer, "Osmanlı Silah Sanayiinde Modernleşme Çabaları”, s. 167. 
Tesisin inşasına başlanmadan evvel ithali düşünülen buhar makinelerinin siparişi verilmeliydi. Bu maksatla bir süredir Osmanlı Devleti'ne Avrupa'dan silah, barut ve sair teçhizat alımlarında aracılık yapan İngiliz müste'min tüccar Mr. Black'in İstanbul'daki daimî temsilcisi ve ticarî işler müdürü Yunan asıllı Hardi'yle temasa geçildi. Tüfekhane Nâzırı Mehmed Tahir Bey ile Hardi arasında 1830 yılında bir anlaşma imzalandı. Anlaşmaya göre Mr. Black, günde 9 saatlik çalışmayla 200-250 tane tüfek namlusu demirini delecek 50 beygir gücündeki bir buhar makinesini İngiltere'deki makine fabrikalarından birine sipariş verecekti. Bunun yanı sıra İngiliz tüfekhanelerinde gerek makineyle, gerekse elle imal edilen tüfek çakmağı takımlarının imaline dair bilgileri içeren kılavuzu ve bu çakmakların her türünden birer örneği de İstanbul'a gönderecekti. Ayrıca Mr. Black, buhar makinesi ve ona ait aksamı kuracak, işletecek ve bakımlarını yapacak mühendis, mimar ve ustaların temin edilip İstanbul'a gönderilmesini de üstlenmekteydi. ${ }^{39}$

Ancak Mr. Black İstanbul'a buhar makinesinin tahmin edilenden daha pahal olduğunu bildirince makinenin getirtilmesi işi bir süreliğine ertelendi. ${ }^{40}$ Öncelik buhar makinelerinin yerleştirilebileceği, Avrupa'daki tüfek fabrikaları standardında yeni bir Tüfekhane-i Âmire inşasına verildi. Mr. Black'in İngiltere'de anlaşarak iş sözleşmesi imzaladığı iki İngiliz mühendis Crife ve Walter, 1832 Mart'ında İstanbul'a geldi. Mühendisler yeni tüfekhanenin nereye inşa edileceği konusunda tespitte bulunmak üzere İstanbul Boğazı kıyılarında keşif gezisine çıktılar. ${ }^{41} \mathrm{Uy}$ gun mahaller olarak Fener Bahçesi (Kadıköy) ya da Yedikule civarındaki Kuşburnu Çayırı'nı gösterdiler. II. Mahmud ise yeni tüfekhanenin Ahırkapı'da yapılmasını istiyordu. Uzun müşavere ve müzakereler sonucu yeni tüfekhanenin nereye inşa edileceği konusunda ricâlin üzerinde karar kıldığı nihai mekân, Dolmabahçe’de bulunan Karabali Çayırı -bugünkü stadyumun bulunduğu alan- oldu. ${ }^{42}$ Yeni Tüfekhane-i Âmire binasının çizim ve projeleri hazırlandıktan sonra inşaata 1832 yılında başlandı ve binaların bir kısmı 1833 yılında tamamlanarak tüfek imal

39 BOA, Cevdet Askerî Tasnifi (C. AS.), 33333, Lef 2, 21 C 1246 (7 Aralık 1830); Takvim-i Vekayi, No: 4, 21 C 1247, s. 3; Yıldız, Neferin Adı Yok, s. 450; Soyluer, "Osmanlı Silah Sanayiinde Modernleşme Çabaları”, s. 167.

40 BOA, Cevdet Bahriye Tasnifi (C. BH.), 4929, 14 M 1248 (13 Haziran 1832).

41 BOA, C. AS, 23360, Lef 1, 12 Ca 1253 (14 Ağustos 1837).

42 BOA, HAT, 29044, tahmini tarih 29 Z 1250 (28 Nisan 1835) olarak verilmiş ama doğrusu 1832 yılı olmalıdır. White, Three Years in Constantinople, II, s. 248; Çelik Gülersoy, "Son 400 Yılda Tophane Semti” VIII. Türk Tarih Kongresi, Ankara 11-15 Ekim 1976, Kongreye Sunulan Bildiriler, III (Ankara: Türk Tarih Kurumu Yayınları, 1983), s. 1640; Yıldız, Neferin Adı Yok, s. 452; Soyluer, "Osmanlı Silah Sanayiinde Modernleşme Çabaları”, s. 168. 
edilmek üzere hizmete sokuldu. Cibalikapı'daki eski Tüfekhane-i Âmire bina ve arsasının ise talibine satılarak, elde edilecek gelirin yeni Tüfekhane-i Âmire'de buhar makinesi mahallerinin inşasına sarf olunması kararlaştırıld ${ }_{1}{ }^{43}$

Dolmabahçe'deki Tüfekhane-i Âmire'de tüfek imalatı makine gücünden yoksun, geleneksel teknolojiyle yürütülmeye çalışılırken, İngiliz mühendisler Crife ve Walter, buhar makinelerinin yerleştirileceği binaların devam etmekte olan inşaatını sık sık denetliyorlardı. İlk planda bina temellerinin kargir olarak inşası uygun görülmüştü. Ancak mühendisler, kargir temellerin buhar makinelerini ve diğer aksamın ağırlığını kaldıramayacağını düşünerek som küfeki taşından çift kat temel inşasını rapor ettiler. Osmanlı yetkilileri, zaten büyük sıkıntılar çekilerek yürütülen inşaatın yeni masraflarla daha da külfetli olacağından buna ilk başta izin vermedi. ${ }^{44}$ Daha sonra bu kadar önemli bir yatırımın, aradaki meblağ farkına feda edilemeyeceğini göz önünde bulundurarak ileride sorun yaşanmaması adına, çaresiz o zamana dek yapılan mahallerin yıktırılarak yeniden inşasını kabullenmek durumunda kaldılar. ${ }^{45}$ Ancak sorun temel inşasının küfeki taşından yapılmasını kabullenmekle bitmiyordu. Bu taş, o zaman için İstanbul'da sadece Bakırköy sahili civarındaki taş ocaklarından çıkarılıyordu. Kolay işlenebilir ve dayanıklı bir taş olduğu için tüm kamu binalarının inşaatında yaygın olarak kullanılan bir yapı malzemesiydi. Bu kadar çok talebe karşın taş ocaklarından çıkarılan taş sınırlı olduğundan inşaat için istenen miktarın çok azı tüfekhaneye verilebiliyordu. Gecikmenin bir diğer sebebi Maliye Hazinesi'nden inşaat için ayrılan tahsisatın tahsilinde yaşanan sorundu. Ödenek düzenli gelmeyince daha fazla usta çalıştırılamıyordu. Bu nedenle bina eminleri, esnaf ve sarraflara borçlanarak açığı kapatmaya çalışıyorlardı. Durum böyle olunca normal şartlarda bir yıl gibi bir sürede bitirilmesi planlanan bina, temel ve duvar inşaatında yaşanan aksaklıklar ve tahsisat gecikmeleri nedeniyle 1835 yılına gelindiğinde hâlâ tamamlanamamıştı. Öte yandan binaları kısa sürede hazır olacak umuduyla İngiltere'ye siparişi verilen buhar makinelerinin aksamı, 1833 yılından beri pey der pey İstanbul'a gönderilmekteydi. ${ }^{46}$ Gelen parçalar yerleştirilecekleri mahaller henüz inşa edilemediğinden, Tüfekhane'nin bir köşesinde kurulacakları günü beklemekteydi. İnşaattaki

43 BOA, HAT, 29129, tahmini tarih 23 Z 1248 (13 Mayıs 1833) olarak verilmiş ancak doğrusu 1833 yılının Nisan ayı başları olmalı; BOA, C. AS., 20235, 23 Za 1248 (13 Nisan 1833). 44 BOA, C. AS., 40789, 10 B 1250 (12 Kasım 1834).

45 BOA, Cevdet Saray Mesalihi Tasnifi (C. SM.), 142, 20 B 1250 (22 Kasım 1834). 46 BOA, C. AS., 16235, 10 Ra 1250 (17 Temmuz 1834). 
aksaklıklar sürerse makineler pas tutacak, bu iş için o âna dek harcanan tüm emek ve para heba olacakt1.

İngiliz mühendisler durumdan epey rahatsızdı 1835 Mayıs'ında Osmanlı Hükümeti'ne kontrat sürelerinin dolmasına bir yıldan az bir zaman kaldığını belirterek, inşaat için gerekli tahsisatın ve inşaat malzemesinin bir an evvel temin edilip, işin hızlandırılmasını talep ettiler. Babıâli, bu isteği yanıtsız bırakmayarak gerekli makamlara talimat verdi. ${ }^{47}$ Süreci hızlandırmak adına vapur binaları inşaatında çalışan 200 kadar taş ve duvar ustasının sayısı arttırıldı. ${ }^{48} 1835 \mathrm{Ka}-$ sım'ında İngiltere'den James Bawnas adında bir mühendis getirtildi. Kendisiyle ilk etapta iki yıllık sözleşme imzalanan Bawnas, Tüfekhane'ye İngiltere'den gelen aletlerin düzenlenmesi ve bakımlarından sorumluydu. ${ }^{49}$ Onu, 1836 Şubat'inda yine makinelerin kurulumunda istihdam edilmek üzere İngiltere'den gelen Wolf ve Wrack adında iki amele ile Marshall adında bir demirci-çilingir ustası izledi. ${ }^{50}$ Robson adlı tüfek kalıpçı ustası, Tüfekhane'nin modelhanesinde çalıştırılmak üzere İstanbul'a gelen bir başka İngiliz'di. ${ }^{51}$ Mart 1836 'da mühendisler Walter ve Crife'ın kontratları bir yıl daha uzatıldı. Bu, Tüfekhane'nin makineli imalata geçmesine en az bir yıl daha olduğuna işaret ediyordu.

Binanın inşaatının bir türlü bitirilememesi II. Mahmud'un öfkesini celp etmişti. Padişahın hışmına uğrayan inşaattan sorumlu bina emini Abdülaziz Agâh Efendi'ye göre baştan beri yaşanan gecikmenin sebebi ne ödenek sıkıntısından, ne de inşaat malzemesi tedarikindeki aksaklıktan kaynaklanıyordu. Bunlar bir şekilde aşılabilirdi. Asıl sorun, bitmek tükenmek bilmeyen kaprisleri ve sınırları zorlayan istekleriyle kendisini bunaltarak çıldırma noktasına getiren iki İngiliz'di. Binaların inşasına memur İngiliz mühendisler, sert mizaçlarından başka asla ve

47 BOA, C. AS., 30714, 3 M 1251 (1 Mayis 1835).

48 Sayıları arttırılan taş̧̧ı ve duvarcı ustalarının aylıklarının düzenli ödenmesine dair buyruldu sûretleri: BOA, C. AS., 52251, tt. 1252 olarak verilmiş. Ancak belgenin mütemmim evrakına göre 1252 Ra-L arası bir tarih olmalı (Haziran 1836-Ocak 1837); BOA, Cevdet Bahriye Tasnifi (C.BH.), 1941, 27 L 1252 (4 Şubat 1837).

49 BOA, C. AS., 35276, Lef 2, 25 Za 1251 (13 Mart 1836). Kendisine Tüfekhane'de çalıştığı süre zarfında Yunus ismiyle hitap edilmişti.

50 Söz konusu İngiliz ameleler ve demirci ustasına Osmanlı yetkililerince kalacak yer tahsis edildiği halde, onlar İstanbul iklimine uyum sağlayamadıklarını bahane ederek geldiklerinden beri gemide ikamet etmekteydiler. BOA, C. AS., 21254, 1 Ra 1252 (16 Haziran 1836).

511839 Eylül'üne kadar Tüfekhane modelhanesinde çalışan Robson, bu tarihten sonra işi bırakınca yerine Georgi adında başka bir kalıpçı ustası getirildi. BOA, Maliyeden Müdevver Defter Tasnifi (MAD. d.), 8926, s. 93. 
kat’a idare ve tasarruf bilmiyorlardı. Abdülaziz Agâh Efendi, gereksiz harcamalar da dâhil olmak üzere Tophane ve Tüfekhane buhar makineleri binaları inşaatı için o zamana kadar sarraflara 800 keseden fazla borç yapmıştı. İngiltere'den ilk geldikleri zaman bizzat kendilerinin hazırladıkları mimari projeyi beğenmeyerek, 1834 yılında projede değişikliğe gitmişler ve o zamana kadar yapılan her şeyi yıktırmışlardı. Bina temelleri adi kara taştan inşa edilebilecekken, İngilizlerin hayalini temelinden duvarlarına kadar tamamıyla som küfeki taşından inşa edilmiş kargir bir yapı süslüyordu. İnşaat sırasında Bakırköy'den gelen her küfeki taşını beğenmeyip, zaten sınırlı miktarda gönderilebilen taşların en beyaz ve temizlerini ayırıyorlardı. Seçme taşları ölçüne aykırı şekilde uzun ve biçimsiz yontturduklarından başka, bazılarını defalarca yerlerine koydurup, çıkararak güya hendeseye uygunluk aramaktaydılar. Bu tavırlarıyla 30 yıldır bu işi yapan taş ustalarını bile bezdirmişlerdi. Abdülaziz Agâh Efendi, inşaatın tamamlanamaması nedeniyle son derece rahatsızlık ve utanç duyduğunu yineledikten sonra sürecin en kısa zamanda sonlandırılacağını ifadeyle padişahın gazabını savuşturmuştu. ${ }^{52}$

1837 yılına girilirken inşaat sürecinin olağan şartlar dâhilinde hızlandırılması gayretleri çerçevesinde az da olsa bir mesafe kat edilebildiği görülür. Artık buhar makinesi binaları inşaatında buhar gücünü torna ve namlu delme tezgâhlarına iletecek büyük dişli çarkların yerlerine konulma safhasına gelinmişti. Dişli çarkların montajı için 1837 yaz mevsimi başında Mr. Black'in İngiltere’den gönderdiği Langlands adında bir usta-mühendis (miller) İstanbul'a geldi. ${ }^{53}$ Buhar makinesi külhanının kontrolünü sağlaması için de Gasbar adlı bir Macar'la sözleşme imzalandı. ${ }^{54} 1838$ Kasım'ında Tüfekhane-i Âmire'deki buhar makinelerinin bulunduğu mahallerin çatısı tamamen örtülmüş ve buhar makinesiyle deneme imalatına başlanmıştı. ${ }^{55}$ Ancak inşaattaki eksiklikler hâlâ tam olarak giderilememişti. Dolayısıyla II. Mahmud'un ömrünün son günlerinde tesis şantiye görüntüsünden bir türlü kurtulamamıştı.

İnşasına 1832 yılında başlanan Tüfekhane-i Âmire'de buhar gücüyle tüfek imalatına geçilebilmesi ancak 6 yıl sonra mümkün olabildi. Dolmabahçe

52 BOA, C. AS., 12493.

53 BOA, C. AS., 21415, Abdülaziz Agâh Efendi'nin 21 Za 1252 (27 Şubat 1837) tarihli istidası; Charles MacFarlane, Turkey and Its Destiny, II (London: John Murray, 1850), s. 367.

54 BOA, Maliyeden Müdevver Defter Tasnifi (Kısaltma: MAD. d.), 8926, s. 110.

55 BOA, C. AS., No, 12493; BOA, C. AS., 26528; BOA, C. AS., 8408, 29 Z. 1261 (29 Aralık $1845)$ tt. Bu belge 1838 Ağustos-Eylül'üne ait bir belgedir. Belge, tasniflemeler sırasında yanlış tarihlendirilmiştir. John Reid, Turkey and The Turks (London: Tyas, 1840), s. 275. 
Tüfekhanesi'ni, buhar makinesi binaları inşaatının sürdüğü yıllarda ziyaret eden üç Avrupalı, yapının ihtişamından bahsederken, inşaatın bu kadar uzun sürede bitirilememesine bir türlü anlam verememekteydi. Bunlardan Tüfekhane'yi 1836 yılında ziyaret eden Miss Pardoe ile 1838 Haziran'ında burada incelemelerde bulunan Fransảnın İstanbul askerî ataşesi Anselme, tesisi ortasında geniş bir avlusu, avlunun ortasında ustaların kullandığı suyun depolandığı mermerden büyük bir havuzu (sarnıç) olan ve avlu iç cephesinin dört bir etrafında imalat atölyelerinin bulunduğu kocaman dikdörtgen bir bina olarak tarif etmekteydi. ${ }^{56}$ Pardoe, başlarında bir Ermeni direktörün olduğu Türk, Bulgar, Rum, Ermeni ve Yahudilerden oluşan 1500 kişilik ekibin burada hayvan gücüyle çalışan delme tezgâhlarında günde 70 tüfek imal ettiklerinden bahsetmekteydi. Kendisine buhar makinesine ait bina inşaatının yakın zamanda sona ereceği ve bundan sonra imalatın makine aracılığıyla gerçekleştirileceği bilgisi aktarılmıştı. ${ }^{57}$ Anselme ise yarısı Türk, yarısı Ermenilerden oluşan 1200 kişilik bir grubun hayvan gücüyle çalışan tezgâhlarda yılda 10.000 adet (günde ortalama 30 adet) 1822 model Fransız piyade tüfeği ürettiğini belirtmekteydi. ${ }^{58} 1838-1839$ yıllarında İstanbul'da bulunan İskoç asıllı John Reid ise daha önce hayvan gücüyle tüfek imal edilen Dolmabahçe Tüfekhanesi'nde 1838 yılı sonlarında 6 torna, 12 namlu delme tezgâhını çalıştıran buhar makinesinin faaliyete geçmesiyle birlikte İskoç asıllı mühendis Langlands'ın idaresinde günde 300 tüfek namlusu delinebildiğinden söz etmekteydi..$^{59}$

İnşa ve modernizasyonu tamamen İngilizler tarafından gerçekleştirilen bu yeni tüfekhanede buhar gücüyle seri tüfek imalatına geçiş Sultan Abdülmecid'e (saltanatı 1839-1861) nasip oldu. 1839 yllında II. Mahmud'un ani ölümüyle tahta geçen oğlu Abdülmecid mevcut ekonomik durumu gözetmeksizin yoğun bir sanayileşme politikası benimsedi. Bu politikadan etkilenen müesseselerin başını doğal olarak silah imalathaneleri çekiyordu. Aslında benimsenen bu politika, sultanın kişisel tercihi değildi. Avrupa'da meydana gelen gelişmeler Osmanlı Devleti'ni bu politikaya sevk etmişti. Avrupalı devletler makineleşmeyi silah

56 Miss Julia Pardoe, The City of the Sultan; and Domestic Manners of the Turks, in 1836, II (London: Henry Colburn, 1837), s. 309. Avigdor Levy, “The Military Policy of Sultan Mahmud II 1808-1839“ (doctoral dissertation), Harvard University, 1968, s. 528.

57 Pardoe, The City of the Sultan, II, s. 309-310.

58 Levy, "The Military Policy of Sultan Mahmud II”, s. 528-529; Yıldız, Neferin Adı Yok, s. 453-454.

59 Reid, Turkey and The Turks, s. 275. 
teknolojisine adapte etmeyi çok iyi becermişlerdi. Silah üretiminde yüz yılı aşkın süredir kullanılan teknik on dokuzuncu yüzyıl başındaki birkaç on yılda büyük değişikliğe uğramıştı. İsabet yüzdesi ve menzili yivsiz (musket-kaval) ${ }^{60}$ tüfeklere oranla çok daha fazla olan, ancak zor doldurulması nedeniyle meydan savaşlarından ziyade avcilıkta ve kale metrislerinde rağbet gören yivli tüfekler (şeşhaneli) ${ }^{61}$, 1826 yılında Henri-Gustave Delvigne (1799-1876) adlı Fransız subayı tarafindan geliştirilen konik uçlu silindir mermi sayesinde kullanımı kolay bir tüfek hâline gelmişti. 1842 yılına kadar mekanizması üzerinde yapılan çalışmalarla daha da mükemmelleşen silah, on dokuzuncu yüzyıl ortalarında Avrupa ordularında yaygın olarak kullanılmaya ve dolayısıyla imal edilmeye başland $1 .{ }^{62}$

Şeşhaneli tüfeklerin imalinde bu gelişmeler yaşanırken geçmişten beri savaş meydanlarının vazgeçilmez silahı çakmaklı kaval tüfeklerin teknolojisinde de değişiklikler meydana gelmişti. 1840 yılında İngiltere'de (İskoçya) çakmaklı kaval tüfekler, kapsüllü çakmaklı tüfeklere dönüştürüldü. Artık çakmaklı kaval tüfekleri, küre şeklindeki kurşun mermiler yerine kâğıt ya da ahşap bir taban üzerine oturtulmuş kurşun mermileri kullanacaktı. Bunun için mevcut çakmaklı tüfekler kapsüllü mermileri kullanacak şekle dönüştürülürken, yeni tüfekler kapsüllü mekanizmaya uygun olarak üretilmeye başladı. ${ }^{63}$ Avrupalı devletler bu silahların en güçlüsünü ve en dayanıklısını imal etme konusunda birbirleriyle kıyasıya rekabe-

60 Namlusu düz ve yuvarlak formda imal edilen, dolayısıyla kolay doldurulabilen, Avrupa dillerinde musket veya smoothbore olarak adlandırılan, Osmanlı askerî terminolojisine de kaval tüfek olarak giren klasik hafif silah türü. Çalışmada bundan sonra yivsiz tüfekler kaval tüfek olarak geçecektir.

61 Namlu gövdesi ve ağzı kurşunu sıkıca tutması için köşegen; çoğunlukla altıgen formda imal edilen Avrupa dillerinde genellikle rifle veya fusil olarak adlandırılan, Osmanlı askerî terminolojisinde de Farsça şeş=altı ve hane=kademe kelimelerinin birleştirilmesinden türetilmiş şeşhaneli tabiriyle yer bulan hafif silah türü. Bu tüfeklerde köşegen form on dokuzuncu yüzyıl ortalarından itibaren değişime uğramıştı. Gelişen teknolojiyle birlikte yuvarlak düz boru şeklinde imal edilen namluların içine yiv açma makineleriyle altı kademe girinti ve çıkıntı (yiv-set) meydana getirmek suretiyle; ya da dışı yuvarlak-düz içi altıgen şekil verilmiş namluların iç köşelerinin birleşim noktalarında ağızdan kuyruğa kadar uzayan düz bir çizgi veya burgu hâlinde set çıkarmak suretiyle günümüz yiv-setli tüfeklerininkine benzer bir üretim tarzına geçildi. Çalışmada bundan sonra yiv-setli tüfekler şeşhaneli tüfek olarak geçecektir.

62 Biographical Dictionary of the History of Technology, ed. Lance Day, Ian McNeil (London: Routledge, 1996), s. 354.

63 William H. McNeill, “The Initial Industrialization of War, 1840-84,” William H. McNeill, The Pursuit of Power: Technology, Armed Force, and Society since AD 1000 (Chicago: University of Chicago Press, 1982), s. 231. 
te girişmişlerdi. Amaç en iyi teknolojiyi geliştirip bunu ve bunun mahsulü olan silahları pazarlamaktı. Emperyalist düşünce diğer üretim alanlarında olduğu gibi bu sahada da etkisini göstermişti.

Osmanlı Devleti'nin Avrupåda yaşanan bu gelişmelerden kendisini izole etmesi mümkün değildi. Müzmin düşmanı Rusyàya karşı ordusunu çağın gerektirdiği silahlarla donatmalıydı. Bunun yolu yeni silahları ve onu üreten teknolojiyi satın almaktan geçiyordu. Nitekim öyle de yapıldı. Osmanlı Devleti, on dokuzuncu yüzyılda, özellikle savaşın sanayileștiği 1840 'lardan itibaren Avrupa'dan yoğun bir silah ithalatına girişti. ${ }^{64}$ Böyle mühim bir konuda tamamen dışa bağımlılığın sakıncaları bilindiğinden yeni geliştirilen silahları satın almak yerine onu üreten teknolojiyi temin edip modern yerli silah sanayi oluşturulmak isteniyordu. Özellikle III. Selim döneminden beri yapılmak istenen şey tam da buydu. Ancak devletin yıkılışına kadar buna tam olarak muvaffak olamayan Osmanlı Devleti bu süreçte sayıları milyonlarla ifade edilecek miktarda silah ve mühimmatı ithal etmek mecburiyetinde kalmıştı.

Modern yerli silah sanayini tesis etmek adına ilk etapta büyük emeklerle vücuda getirilen buhar makineleri aracilığılla mevcut teknolojide silah üretimine, yani 1822 model Fransız piyade tüfeği (çakmaklı misket tüfeği) imaline ağırlık verildi. Zaten makine gücüyle silah imalatı yeni başlamış sayılırdı. Tam da bu niyetle üretime başlanmışken beklenmedik bir problemle karşılaşıldı. 1840 yılında Tüfekhane'deki makine binasının duvarlarında geniş çatlaklar meydana gelmişti. İnşası büyük sıkıntı ve tartı̧malar eşliğinde beklenenden çok uzun süren ve henüz kısa bir müddet evvel tamamlanarak hizmet vermeye başlayan bir bina, doğal afetler dışında nasıl hasar görebilirdi? Sebebi araştırılmış ve binanın, büyük çarkların ağıllığını taşıyacak kapasitede inşa edilmediği tespit edilmişti. Bu çarklar ufaklarıyla değiştirilmediği takdirde ileride binada daha büyük çatlakların meydana gelebileceği, hatta yıkımların yaşanabileceği rapor edilmişti. Osmanlı Devleti bu nedenle İngiltere'ye küçük çarklarla, bunları döndürecek iki mil sipariş vermek zorunda kald. ${ }^{65}$ Yeni çarklar gelinceye kadar mevcut düzenekle imalatın devamında bir sakınca olmadığı bildirildiğinden, tedirgin vaziyette de olsa tüfek imal edilmeye çalışıldı. Bu arada 1835 Kasım’ından beri Tüfekhane-i Âmire hizmetinde çalışan buhar makinesi teknik sorumlusu James Bawnas'ın -nam-1

64 Bu konuda ayrıntılı bilgi için bkz. Yıldız, Neferin Adı Yok, s. 433-473; Soyluer, "Osmanlı Silah Sanayiinde Modernleşme Çabaları”, s. 249-316.

65 BOA, İrade Meclis-i Vâlâ Tasnifi (İ. MVL.), 102, Lef 3, 4 C 1256 (2 Ağustos 1840) tarihli irade. 
diğer Yunus- sözleşmesi 1839 yılının sonunda dolmuştu. Tüfekhane'de kendisine ihtiyaç kalmadığı gerekçesiyle sözleşme yenilenmeyerek İngiltere'ye gönderildi. Onunla birlikte buhar makinesinde görev yapan çarklardan sorumlu diğer İngiliz mühendis Langlands' $ı$ ise sözleşmesi uzatıldı. Çünkü Langlands, yanına verilen mühendishane öğrencilerinden Esad, İzzet, Kâmil ve Şakir Efendilere buhar makinesinin işletme prensibini öğretmeye devam ediyor ve de gayet verimli çalışıyordu. Kendisine hâlâ ihtiyaç olduğu gerekçesiyle 1840 yılına girilirken yeniden sözleşme imzalandı. ${ }^{66} 1840$ Eylül'ünde maiyetinde 9 ay süreyle çalıştırılmak üzere İngiltere'den Jamie-James? adında bir demirci ustası getirtildi. ${ }^{67}$

Bawnas'ın sözleşmesinin uzatılmamasının en önemli sebeplerinden biri artık onun yerini dolduracak bir Müslüman'ın varlığından kaynaklanıyordu. O isim, II. Mahmud zamanında hafif silah üretiminde eğitim görmesi için İngiltere’ye gönderilmiş ve burada tahsilini tamamladiktan sonra İstanbul'a dönerek Dolmabahçe'deki Tüfekhane-i Âmire'de göreve başlayan Bekir Paşa'ydı. 25 Mayıs 1841 tarihinde Tüfekhane-i Âmire'yi ziyaret eden Elizabeth Mary Grosvenor, Bekir Paşa'yı ve onun şahsında Tüfekhane-i Âmire'yi ayrıntılı olarak tasvir etmiştir. Grosvenor, Bekir Paşàyı tarif ederken onun, istisna olarak Osmanlı meritokrasisinin dışından gelmiş, soylu bir aileye mensup Osmanlı idarecisi olduğundan bahseder. On dört aydır Tüfekhane'de görev yapan Bekir Paşa, çoğunluğu Mehmet Ali Paşa’nın baskılarından kaçmış Mısırlılardan oluşan tüfekhane iş̧̧ilerinin gerçekleştirdiği silah üretiminin her safhasını bizzat denetlemekte ve tüm sorunlarla yakından ilgilenmektedir. Grosvenor’a göre Bekir Paşa’nın gayretleri sayesinde bu berbat imalathanede günde 80 tabanca ve çok sayıda tüfek imal edilebilmektedir. ${ }^{68}$

Grosvenor'dan bir yıl sonra İstanbul'a gelerek üç yılını burada geçiren İngiliz subay Charles White, Dolmabahçe'deki Tüfekhane-i Âmire'de Bekir Paşa idaresinde 300 kişinin çalıştığından ve bunların büyük çoğunluğunu Mısır'dan veya İbrahim Paşảnın Suriye'deki ordusundan kaçan askerlerin oluşturduğundan bahsetmektedir. ${ }^{69}$ White, Bekir Paşa’nın yürürlüğe soktuğu işbölümü sayesinde

66 BOA, MAD. d. 8926, s. 380-381; BOA, C. AS., 18221, Ahmed Fethi Paşa’nın 23 Ra 1256 (25 Mayıs 1840) tarihli tezkiresi.

67 Şahsın ismi aynı belge içerisinde iki farklı şekilde geçmektedir. BOA, İrade Dâhiliye Tasnifi (I. DH.), 1069, 9 Ş 1256 (6 Ekim 1840) tarihli irade; BOA, MAD. d., 8926, s. 388.

68 Elizabeth Mary Grosvenor, Narrative of a Yacht Voyage in the Mediterranean During the Years 1840-1841, I (London: John Murray, 1842), s. 346-348.

69 Grosvenor ve White'ın bahsettikleri Mısırlılar, demir-çeliği işlemelerindeki maharetleriyle tüm Dünya’da şöhret bulan Şamlı demirci ustaları olmalıdır. Söz konusu ustalar, az ücretle 
her ustanın yalnızca uzmanı olduğu parçanın imal ve montajını üstlendiğini ve bu sayede daha kaliteli ve daha fazla sayıda silah üretilebildiğinden söz etmektedir. Tüfekhane'deki meşhur buhar makinesine de değinen İngiliz subay, idaresini yakın geçmişe kadar İngilizlerin üstlendiği makinenin artık Türkler tarafından idare edildiğinden bahsetmektedir. Elli beygir gücündeki bu büyük aygıtın, tesisteki diğer tezgâhlar makineyle çalışmaya uygun olmadığından sadece namlu delme tezgâhlarını işlettiğini; bunun da enerji, zaman ve üretim kaybına neden olduğunu sözlerine ekleyen White, bu kötü şartlarda bile Tüfekhane'de ayda ortalama 800 tüfek veya tabanca üretilebildiğine dikkat çekmektedir. ${ }^{70}$

Gerçekten de makineli üretimin ilk zamanlarında çakmaklı misket tüfeklerin sadece namlularının delinmesi ve torna işleri buhar makinesiyle işleyen tezgâhlarda yapılabiliyordu. Diğer tezgâhlar makine ile çalışmaya uygun olmadığından tüfeklerin namlu ve dipçik haricindeki aksamı ameleler tarafından elle imal ediliyordu. Bu yüzden stoklarda çok sayıda namlu ve dipçik olmasına rağmen, tüfeğe ait diğer parçalardan yok denecek kadar az bulunmaktaydı. Dolayısıyla tüfek imalatı istenen hızda ilerlemiyordu. Bu sorunu gidermek için tüfeklerin namlu haricindeki diğer aksamının da buhar gücüyle çalışan tezgâhlarda imaline karar verilerek 1841 ve 1842 yıllarında İngiltere'den gerekli tezgâhlar ithal edildi. ${ }^{71} 1826$ yılında Londra'dan İstanbul'a gelen ve o tarihten beri Tophane ve Humbarahane'de başarılı hizmetleri görülen kalıpçı Petro, 1839 yılından beri Tüfekhane'de görev yapan kalıpçı Georgie'nin yerine yeni yapılacak tüfeklerin kalıplarını hazırlamak üzere 1843 yılında Tüfekhane-i Âmire'ye nakledildi. ${ }^{72} \mathrm{Gerekli}$ tezgâhların kurulumu, İngiltere'den getirtilen küçük çaplı çarkların yerlerine konulması, tamir işlemleri ve diğer eksiklerin tamamlanması 1843 Mart'ını buldu. ${ }^{73}$ Tüfek imalatının büyük bölümünün buhar gücüyle gerçekleştirilmesi adına yapılan bu düzenlemeler sırasında İngiltere'den birkaç tüfek ustası getirtilerek çakmaklı misket tüfeklerinden 200 tanesi 1840 model kapsüllü kaval tüfeğe dönüştürüldü. 1843 Mart'ında da İskoçya'da geliştirilen 1842 model kapsüllü $k a-$ val tüfeklerden 25 tane imal edildi. Aynı ay içerisinde Tüfekhane'de ilk deneme

çok işin beklendiği İbrahim'in Suriye'sinden, daha adil şartların sunulduğu Osmanlı payitahtına gelmeyi-kaçmayı (!) tercih etmişlerdi.

70 White, Three Years in Constantinople, II, s. 249.

71 Soyluer, "Osmanlı Silah Sanayiinde Modernleşme Çabaları”, s. 186.

72 Tüfekhane-i Âmire'deki görevi 1847 Aralık'ında sona eren Petro, Tophane-i Âmire'deki vazifesine geri dönmüştür. BOA, İ. DH., 8547, 25 M 1264 (3 Ocak 1848) tarihli irade.

73 BOA, C. AS., 26375, Lef 3, makine ve tamir masrafları için ayrılan tahsisatın hazırlandığına dair Maliye Nazırı Safvetî Paşa'nın 7 B 1259 (3 Ağustos 1843) tarihli takriri. 
üretimleri 1839 yılında gerçekleştirilen 1826 Model Delvigne ağızdan dolar şeşhaneli tüfeklerinden de 25 tane imal edildi. Dönüşüm ve imal işleri maliyetli olduğundan ve bunun sağlıklı ve seri bir şekilde gerçekleştirilebilmesi Tüfekhane'de o an bulunmayan tezgâh ve gereçlere bağlı bulunduğundan bu uygulama çok uzun soluklu olmadı. Üretimi zor ve maliyeti de bir o kadar fazla olan bu iki tüfek türünün, üretimlerine mahsus makine, teçhizat ve teknisyenler Avrupa'dan getirtilinceye kadar -deneme amaçlılar dışında- bir daha dönüşümü ve üretimi yapılmadı. ${ }^{74}$

Ancak bundan sonraki ilk hedef Osmanlı ordusunda kullanılmakta olan tüfeklerin kapsüllüye dönüştürülmesi ve yeni imal edilecek tüfeklerin de kapsül mekanizmalı olarak üretilmesi olacaktı. Gerekli makine ve araç gereçlerin temini ile işi öğretecek Avrupalı uzmanlara verilecek ücretlerin karşılanması için Tüfekhane-i Âmire tahsisatının arttırılmasına karar verildi. Konu Dâr-1 Şûrâ-yı Askerî ve Meclis-i Vâlâda defalarca müzakere edildi. Neticede 1842 yılından itibaren Tüfekhane-i Âmire'ye sermaye olarak peşinen 100.000 kuruş ve imalata mahsuben de her hafta 40.000 kuruş verilmesi uygun görüldü. ${ }^{75}$ Arttırılan tahsisatla birlikte makineler için para biriktirilmeye başlandı. Ancak makinelerin nereden temin edileceği, piyasada birkaç tipi bulunan tüfeklerden hangisinin daha kullanışl olduğu, dönüşüm mü yoksa üretim için mi makine ve teçhizat getirtilmesinin faydalı olacağı konuları askerî ve idarî mahfillerde -yer yer şiddetli tartışmalarla geçen- uzun soluklu müzakerelere neden olmaktaydı. 1847 yılında, kapsüllü kaval tüfek ve ağızdan doldurulur şeşhaneli tüfek imaline mahsus makine ve tezgâhların nelerden oluştuğuna ve yaklaşık ne kadar bir maliyetle, Avrupa'nın hangi sanayi ülkesinden temin edilebileceğine dair 1842 yılından beri sürdürülen müzakereler ve yürütülen çalışmalar nihayet buldu. Makinelerin temini için Tophane-i Âmire'ye teçhizat almak üzere 1847 yılında İngiltere'ye gönderilen Mirliva Halil Paşa görevlendirildi. Halil Paşa Londra'dan dönüşünde Belçika'ya uğrayarak burada bulunan tüfek fabrikalarında incelemelerde bulundu. Özellikle Liége'de bulunan devlete ait tüfek fabrikasındaki gözlemleri sonucu İstanbul'a verdiği rapor doğrultusunda kapsüllü kaval ve şeşhaneli tüfeklerin imal ve dönüşümüne mahsus makine, tezgâh ve teçhizatın Belçika’nın Liége Devlet Tüfekhanesi'nden teminine karar verildi. Aynı fabrikadan makine ve aletlerin kurulumunu yapmak ve Tüfekhane-i Âmire amelesine nasıl kullanıldıklarını öğretmek maksadıyla 10 kişilik usta ve teknisyen ekibi istenecekti. Bu önemli projenin 110.000 kuruşa mal olacağı tahmin ediliyordu. ${ }^{76}$

74 Soyluer, "Osmanlı Silah Sanayiinde Modernleşme Çabaları”, s. 187-188.

75 Soyluer, "Osmanlı Silah Sanayiinde Modernleşme Çabaları”, s. 187.

76 Soyluer, “Osmanlı Silah Sanayiinde Modernleşme Çabaları”, s. 195-196, 225-226. 
Belçika'dan ithal edilen kapsüllü kaval ve şeşhaneli tüfek imal tezgâh ve teçhizatının ilk etapta yalnızca kapsüllü kaval tüfek imaline mahsus olanları İstanbul'a gönderilecekti. Çünkü yeni tezgâhların kurulumunun nereye yapılacağı büyük bir sorun teşkil ediyordu. Dolmabahçe'deki Tüfekhane-i Âmire'ye ait binalar, inşaatı her geçen yıl ilerleyen Dolmabahçe Sarayı'na ilhak olunduğundan kademeli olarak terk ediliyor ve yıktırılarak yerlerine saraya ait yeni binalar yapılıyordu. İlk partisi gelmek üzere olan ve ilerleyen zamanlarda geri kalanları da gelecek olan makine ve tezgâhların kurulumu için şiddetle yeni bir mekâna gereksinim duyulmaktaydı. Sultan Abdülmecid, hemen uygun bir mahallin bulunarak, inşa ve düzenleme faaliyetlerinin başlatılmasını emretti. İnşaat için en uygun yerin yeni sanayi imar bölgesi Zeytinburnu fabrikalar yerleşkesi olduğuna kanaat getirilerek 1848 yazına girilirken burada gerekli binaların inşasına başland. ${ }^{77}$ Bundan sonraki 10 yıllık süreçte Dolmabahçedeki tüfekhane, en son buhar makinelerinin bulunduğu bina olmak üzere tedricen tahliye edildi ve Osmanlı Devleti'nin modern ve aynı zamanda son tüfek fabrikası Zeytinburnu'nda tesis edildi.

Belçikalı montaj ekibi, 1848 yılı sonlarında Liége'den İstanbul'a gelen ilk parti tezgâh ve teçhizatı Zeytinburnu'ndaki bina inşaatı henüz tamamlanmadığ1 ve şartları uygun olmadığı için Dolmabahçe Tüfekhanesi'ne kurdu. Bundan sonra gelecek olan tezgâhların ise inşaatı tamamlandığı takdirde Zeytinburnu Demir Fabrikası bitişşğindeki yeni tesise kurulması kararlaştırıldı. ${ }^{78}$ Dolmabahçe Tüfekhanesi'nde kurulumları tamamlanan makine ve tezgâhlarda ilk kapsüllü kaval tüfek imalatı Belçikalı ustalar tarafından 1849 yılında gerçekleştirildi. Bu ilk denemede 1847 model kapsüllü kaval tüfeklerden 200 tane imal edildi. ${ }^{79}$ Tüfekhane, yeni tüfeğin imalini bilen yeterli usta ve ameleden yoksun olduğundan, Belçikalı usta ve teknisyenlerin uzun müddet istihdamı da maddi anlamda büyük külfet doğuracağından işin tekniğini öğrenmeleri için Mekteb-i Harbiye’den Rüstem ve Said Efendiler aynı yıl Belçika’ya gönderildi. ${ }^{80}$ Yeni makinelerin Belçika'dan tedariki, bunları kuracak ve kullanacak usta ve teknikerlerin

77 BOA, İ. DH, 8949, 14 R 1264 (20 Mart 1848) ve BOA, İ. MVL, 3036, 14 C 1264 (18 May1s 1848) tarihli iradeler; BOA, MAD. d., 8932, 29 B 1264 (1 Temmuz 1848) tarihli ilm ü haber sûreti, s. 250-251.

78 BOA, I. DH., 11083, 3 B 1265 (26 Mayıs 1849) tarihli irade; BOA, Sadaret Mektubî Mühimme Kalemi Evrakı Tasnifi (A. MKT. MHM.), 13-53.

79 Soyluer, "Osmanlı Silah Sanayiinde Modernleşme Çabaları", s. 197.

80 Takvim-i Vekayi, No: 413, 17 Za 1265, s. 4. 
Belçika'dan getirtilmesi, bu tüfeğin imalini öğrenmek için Belçika’ya öğrenci gönderilmesi, Tüfekhane'de yeni bir dönemin de başlangıcı oldu. 1830'lardan beri Tüfekhane ve diğer Osmanlı fabrikalarında süre gelen İngiliz etkisi artık yerini Avrupa’nın yeni makine üreticisi konumuna yükselen Belçika ve Fransa etkisine bıraktı. 1860'ların ortalarına kadar devam eden bu etki sonucunda İstanbul ve çevresinde oluşturulmaya çalışılan Osmanlı sanayi bölgesi, İngiliz teknik personelin yanı sıra bir o kadar Belçikalı ve Fransız teknisyen ve ustayla doldu ${ }^{81}$

Belçikalı ekip, yeni gelen tezgâhların kurulumu ile meşgul iken, kapsüllü kaval tüfek imal edebilecek başka usta bulunmadığından Dolmabahçe Tüfekhanesi'ndeki deneme üretiminden sonra aşağı yukarı bir yıl boyunca kapsüllü kaval tüfek imal edilemedi. Bu zafiyete bir an önce son vermek isteyen Osmanlı askeri seçkinleri, 1850 Mayıs'ında kapsüllü kaval tüfek imali konusunda gayet yetenekli olduğu duyumunu aldıkları İtalyan tüfek ustası Toronna ile sözleşme imzaladı. ${ }^{82}$ Toronna, kapsüllü kaval tüfek imalini tahsil maksadıyla Belçika’da bulunan Rüstem ve Said Efendiler öğrenimlerini tamamlayıp İstanbul'a dönünceye ve Tüfekhane personeli söz konusu tüfeğin imal tekniğini iyice öğreninceye kadar Tüfekhane'de görev yapacaktı. Toronna, İstanbul'a gelir gelmez Tüfekhane'de kendi sistemini kurdu. ${ }^{83}$ Tüfek üretiminde kendisine yardımcı olması için German adında bir tüfek ustasını işe aldırdı. ${ }^{84} 1850$ Ekim'inden itibaren ikisi kontrolünde 1850 model kapsüllü kaval tüfek imaline başlandı. Toronna ve ekibinin performansından gayet memnun olan Osmanlı yetkilileri, yerli üretime etkinlik ve süreklilik kazandırmak adına İstanbul'daki Müslüman ve reaya çocuklarının yetenekli ve gönüllülerinden ilk etapta 25 kişilik bir grubun seçilerek Tüfekhane'de istihdamına karar verdi. Teşvik maksadıyla kendilerine 1,5 veya 2 kuruş yevmiye verilecek bu çocuklar, Toronna ve ekibinden kapsüllü kaval tüfek imalinin tüm inceliklerini öğreneceklerdi. Öğrendikleri bu kıymetli bilgiyi kendilerinden son-

81 MacFarlane, Turkey and Its Destiny, II, s. 358-368. M. Abdolonyme Ubicini, Letters on Turkey, I, trans. Lady Easthope (London: John Murray, 1856), s. 341.

82 Toronna, görev süresi boyunca aylık 4000 kuruş maaş alacaktı. BOA, Meclis-i Vâlâ Evrakı Tasnifi (MVL.), 335-15, 15 Ca 1269 (24 Şubat 1853) tarihli takrir; BOA, I. MVL., 10086, 21 Ca 1269 (2 Mart 1853) tarihli irade; BOA, MAD. d., 8934, s. 37.

83 Toronna, imalatını gerçekleştireceği 1850 model kapsüllü tüfekler için Avrupa'dan bir takım alet ve tezgâhların alınmasını istemişti. Toronna’nın istediği şeyler çok maliyetli şeyler olmadığından hemen getirtilerek bir iki aylık süreçte kurulumları yapılmış ve tüm bu hazırlıkların ardından söz konusu tüfeğin seri imalatına geçilmişti. Bkz. BOA, MAD. d., 8932, s. 208, 216, 225.

84 BOA, MAD. d., 8934, s. 37. 
raki nesillere usta-çırak ilişkisi çerçevesinde aktaracaklar ve Osmanlı Devleti silah üretiminde Avrupa'ya bağımlılıktan kurtulacaktı. Çok sayıda talibin arasından seçilen topluluk, 1852 yılından itibaren Tüfekhane'de çalışmaya başladı ${ }^{85} \mathrm{Bu}$ arada Belçika'ya siparişleri 1847 yılında verilen alet ve tezgâhların güncellenerek modernize edilmişs son parçaları 1853 yılında İstanbul'a geldi. Belçikalı teknisyenler bu son parçaların kurulumunu gerçekleştirdi. ${ }^{86}$ Böylelikle Osmanlı Devleti'nde kapsüllü kaval tüfek imalatı tekâmül etmiş oluyordu. Osmanlı kapsüllü kaval tüfek üretiminin emektarı Toronna ve ekibinin gayretleriyle bu makinelerde ayda ortalama 1000 kapsüllü kaval tüfek imal etme başarısı gösterilmişti. Ayrıca tesiste ayda 1500 tane çakmaklı kaval tüfek de kapsüllü kaval tüfeğe dönüştürülebilmekteydi. ${ }^{87}$ Kırım Savaşı sırasında bu üretim yoğunluğu, müttefik kuvvetlerin Osmanlı silahlarını sayı ve kalite bakımından yetersiz bularak kendi silahlarını tercih etmeleri ve Osmanlı ordularına da bunlardan dağıtmaları -satmaları!- nedeniyle bir hayli düşüş göstermişti. Ancak Toronna ve ekibi, Kırım Savaşı sona erene kadar üretim süreci yavaşlayan Tüfekhane'deki görevlerine devam ettiler. ${ }^{88}$

Kapsüllü kaval tüfek imalini çözüme kavuşturan Osmanlı Devleti için sıra şeşhaneli tüfek üretimine gelmişti. Zaten buna mahsus makine ve tezgâhların daha önceden siparişi verilmiş, ancak öncelik kapsüllü kaval tüfek imalinde olduğu için şeşhaneli tüfek makine ve tezgâhları Belçika'dan gelen en son partiye bırakılmıştı. Makinelerin Dolmabahçe Tüfekhanesi ve Zeytinburnu'nda inşaatı süren yeni silah fabrikasındaki yerlerine monte edileceği sırada patlak veren Kırım Savaşı,

85 BOA, I. MVL., 8132, Lef 3, 6 C 1268 (28 Mart 1852) tarihli irade; MAD. d., 8934, $11 \mathrm{~B}$ 1268 (1 Mayıs 1852) tarihli ilm ü haber sûreti, s. 137-138.

86 BOA, MAD. d., 8934, s. 54.

87 Belçika İçişleri Bakanlığı bölüm şeflerinden istatistikçi Xavier Heuschling, 1850’lerin başlarında Dolmabahçe Tüfekhanesi'nde tamir ve dönüşüm haricinde yılda 30.000 adet kapsüllü tüfek üretildiğini belirtmektedir. Xavier Heuschling, L’empire de Turquie (Bruxelles: Tarlier, 1860), s. 153. İstanbul'da 1746-1762 yılları arasında on beş yıl İngiliz elçiliği yapmış James Porter'ın torunu George Larpent, dedesinin anılarını da ilave ederek 1839-1854 yılları arası Türkiye’sinin koşullarını anlattığı eserinde, 300 işçinin çalıştığı Dolmabahçe Tüfekhanesi'nde tamir edilenler hariç, yılda 30.000 tane tüfek imal edilebildiğini tekrarlamaktadır. Larpent'in, Heuschling ve Charles White'ın anlatılarından harmanlayarak meydana getirdiği net bir şekilde görülen söz konusu kısım için bkz. George Larpent, Turkey: Its History and Progress From the Journals and Correspondence of Sir James Porter, II (London: Hurst \& Blackett, 1854), s. 307. Bu rakam, devrin Osmanlı resmî kayıtlarındaki verilere göre abartılı gözükmektedir. Bkz. Soyluer, "Osmanlı Silah Sanayiinde Modernleşme Çabaları”, s. 220-221.

88 BOA, MAD. d., 8934, s. 154. 
planlanan şeşhaneli tüfek imal faaliyetlerinin ertelenmesine neden oldu. Bu yüzden savaş boyunca Tüfekhane-i Âmire'de sadece kapsüllü kaval piyade tüfeği imal edilebildi. Ancak bu süreçte boş durulmadı. Şeşhaneli tüfek üretimini yoluna koymak ve seri imalata geçebilmek adına Belçikàya şȩ̧haneli tüfek imaline mahsus birkaç tezgâh ve teçhizat daha sipariş edildi. ${ }^{89}$ Yeni gelen tüm makine ve tezgâhlar Zeytinburnu Silah Fabrikası'na monte edildi. ${ }^{90}$ Dolmabahçe Tüfekhanesi'ndeki buhar makinesi ve ona ait tüm aksam da savaş sırasında Zeytinburnu'ndaki fabrikaya taşındı. Böylece Dolmabahçe Tüfekhanesi'nin tasfiye süreci tamamlanmış oldu. ${ }^{91} 1857$ yılının ortalarına gelindiğinde Zeytinburnu Silah Fabrikası'nda şeşhaneli tüfek imaline başlamak için tüm hazırlıklar aşağı yukarı tamamdı.

1857 yılında Osmanlı ordusundaki tüm tüfeklerin şeşhaneli olması kararlaştırıldı. ${ }^{92}$ Kararın alınmasında Osmanlı askeri kanaat önderlerinin Kırım Savaşı'nda İngiliz askerlerinde görüp beğendikleri 1853 model Enfield yiv-setli tüfeklerin büyük etkisi vardı. Bu konuda padişahı ikna etmeleri de pek zor olmadı. Öncelikle Enfield lardan şartlar elverdiği kadarı ithal edilecek, kalanı için Zeytinburnu'nda yeni bir üretim sahası meydana getirilecekti. Söz konusu tüfeği tüm parçalarıyla imal edecek makineler için İngiltere'de bir fiyat araştırması yaptırıldı. Ancak makineler çok pahalı olduğundan bu tasarıdan vazgeçildi. Onun yerine Belçika’dan getirtilen makine ve tezgâhlarda Delvigne şeşhaneli tüfeklerinden imal edilecek, eldeki kapsüllü kaval tüfekler, namlularına yiv açılmak suretiyle şeşhaneliye dönüştürülecekti.

Bunun için hemen harekete geçildi. Üretim ve dönüşüm işlerinin doğru ve sağlıklı bir şekilde yürütülebilmesi için ustabaşılığa, 1850 yılından beri Tüfekhane'de görev yapan tecrübeli isim German getirildi. Ona Belçikalı ekip yardım edecekti. Mühendishane öğrencileriyle, Karadeniz Boğazı istihkâmlarındaki topçu askerlerinden seçilen 30 kişilik bir grup, tüfek imalini öğrenmek üzere Fransa’ya gönderildi. Ayrıca Hassa, Dersaadet, Anadolu ve Rumeli ordularından seçilen 200 asker, şeşhaneli tüfek imalatında çalıştırılmak üzere Zeytinburnu Silah Fabrikası'na

89 BOA, Hariciye Nezâreti Evrâkı Mektubî Kalemi Tasnifi (HR. MKT), 166-43, 11 Ra 1273 (9 Kasım 1856).

$90 \mathrm{Bu}$ makine ve tezgâhların yerleştirileceği mahallerin inşasının İstirati Kalfa'ya ihale olunduğuna dair 14 C 1271 (4 Mart 1855) tarihli irade. BOA, İ. DH., 20464, 14 C 1271.

91 Dolmabahçe'deki makinelerin tamamı Zeytinburnu'na nakledildiğinden, bunların kurulabilmesi için yerleşke dâhilinde ek binalara ihtiyaç duyuldu. Gerekli binaların bir an evvel inşasına dair 1 Nisan 1856 tarihinde bir irade yayınlandı. BOA, I. DH., 22540.

92 Yüzbaşı Hakkı, Esliha-yı Nariyye-i Hafife, 1281 (1864), İstanbul Üniversitesi Nadir Eserler Kütüphanesi (İUKKTB) TY 81612, s. 34. 
getirildi. Avrupa’da tüfek imali hususunda eğitim görmüş Bekir, Rüstem ve Said Paşa'lar üretimin genel sorumluları olacaktı. ${ }^{93}$ Bir yandan Fransa, Belçika ve Avusturya gibi devletlerden şş̧̧ $h a n e l i$ tüfek ithal edilip askerlere dağıtılmak üzere ordu merkezlerine gönderilirken, diğer taraftan askerlerin ellerindeki kapsüllü kaval tüfekler toplanarak şeşhaneliye dönüştürülmek üzere Harbiye ambarlarında depolanıyordu. ${ }^{94}$ Hazılıkların ilk etabı tamamlandıktan sonra 1857 yılı sonlarında imalat ve dönüşüm işlemlerine başland. İlk zamanlar ayda 250 adet yeni şeşhaneli tüfek üretilirken, 750 civarında kaval tüfek de şeşhaneli tüfeğe dönüştürülebiliyordu. ${ }^{95}$

Beklentilerin çok altında kalan bu rakamın daha yukarı çekilebilmesi, ayda hiç olmazsa 500 adet yeni şeşhaneli tüfek imal edilebilmesi ve 3000 adet kaval tüfeğin de şeşhaneliye dönüştürülebilmesi hedefleniyordu. Daha fazla tahsisata, daha çok sayıda tezgâha ve bir o kadar kalifiye elemana muhtaç olan bu hedefi gerçekleştirmek üzere birtakım girişimlerde bulunuldu. 1859 yılında Zeytinburnu Silah Fabrikası'nda çalıştırılmak üzere Fransa'nın Châtellerault Silah Fabrikası'nda görevli Grandery adında bir ustabaşı ve ekibi ile sözleşme imzaland. ${ }^{96} 1860$ Aralık'ından itibaren sadece bu işte kullanılmak üzere Zeytinburnu Silah Fabrikası'na her ay 160.000 kuruş daha ödenek ayrılmasına karar verildi. ${ }^{97}$ Ancak yaşanan birtakım aksaklıklar istenen şeylerin bir an önce gerçekleşmesine engel oluyordu. Kendisiyle 1859 yilı sonunda anlaşma imzalanan Fransız ustabaşı Grandery, kendisine teklif edilen maaş ve diğer imkânları yetersiz bularak İstanbul'a gelmekten vazgeçmişti. ${ }^{98}$ Ona sunulan şartlarda İstanbul'a gelmeyi kabul edecek başka bir ustabaşı ve ekibinin bulunması ve iknası ise neredeyse bir yıl sürdü. Sonunda 1861 yılında Touvel silah fabrikasında çalışan Munier adlı bir ustabaşı-kontrolörle anlaşılabildi. ${ }^{99}$ Aynı yılın haziran ayında onun maiyetinde çalıştırılmak üzere Châtellerault Silah Fabrikası'ndan Massaux, Baudroux, Rousseau ve Macquart adlı ustalarla da kontrat yapıldı. ${ }^{100} \mathrm{Bu}$ krizin aşılmasının ardın-

93 Soyluer, "Osmanlı Silah Sanayiinde Modernleşme Çabaları”, s. 200.

$94 \mathrm{Bu}$ konuda ayrıntılı bilgi için bkz. Soyluer, "Osmanlı Silah Sanayiinde Modernleşme Çabaları", s. 249-316.

95 Soyluer, "Osmanlı Silah Sanayiinde Modernleşme Çabaları”, s. 200.

96 BOA, HR. MKT., 317-97, 16 Ca 1276 (11 Aralık 1859) tarihli sadaret tezkiresi.

97 BOA, A. MKT. MHM., 761-13, 23 Z 1277 (2 Temmuz 1861).

98 BOA, HR. MKT., 335-26, 29 L 1276 (23 Mart 1860) tarihli sadaret tezkiresi.

99 BOA, HR. MKT., 374-40, 10 L 1277 (21 Nisan 1861). Talep edilen ustabaşıyla imzalanan kontratın İstanbul'a gönderildiğine dair Paris Maslahatgüzârı Agop Efendi'nin tahriratı: BOA, HR. MKT., 374-82, 13 L 1277 (24 Nisan 1861).

100 BOA, Hariciye Nezâreti Paris Sefâreti Belgeleri Tasnifi (HR. SFR. 4), 48-6. 
dan Zeytinburnu Silah Fabrikası'na her ay verilmesi plânlanan 160.000 kuruşun ödenmesinde yaşanan aksaklıklar gündeme oturdu. Diğer sahalara, özellikle donanma harcamalarına ayrılan tahsisatın denkleştirilmesi için hazine büyük çaba sarf ettiğinden Tüfekhane tahsisatını karşılamada güçlükler yaşanıyordu. Söz konusu meblağ düzenli olarak verilemediğinden imalat ve dönüşüm işleri de eldeki para oranında yürütülebiliyordu.

Şeşhaneli tüfek imalatı ve dönüşüm işlemlerine etkinlik kazandırılması 1862 yılı sonlarını buldu. Artık Zeytinburnu Silah Fabrikası'nda ayda 750 adet yeni şeşhaneli tüfek üretilebiliyor, 1000 civarında kapsüllü kaval tüfek de şeşhaneliye dönüştürülebiliyordu. Bu miktar, beş yıl önceye oranla iyi bir rakam olmasına rağmen redif birlikleri de dâhil tüm Osmanlı ordusunun şeşhaneli tüfekle donatılması tasarısı göz önüne alındığında yerli üretim için asla yeterli bir sayıyı ifade etmiyordu. Avrupa'dan ithal edilenlere ilaveten, yerli üretim silah sayısını artırmak için 1863 yılında Zeytinburnu Silah Fabrikası'nın aylık tahsisatına geçici olarak zam yapıldı. ${ }^{101}$ Öte yandan aynı yıl Hassa ve Dersaadet ordularından başlamak üzere Osmanlı ordusunun 1853 model Enfield şeşhaneli tüfeklerle donatılması kararı alındı. İlk etapta sadece ithal yolla temin edilebilecek tüfeklerin ilerleyen zamanlarda üretimine de geçilmesi planlanmaktaydı. O zamana kadar Zeytinburnu Silah Fabrikası'nda şeşhaneliye dönüştürülen ve Delvigne tarzında üretilen şeşhaneli tüfekler ise redif birliklerine dağıtılacaktı. ${ }^{102}$

1863 yılından itibaren ithaline başlanan Enfield tüfeklerinden Zeytinburnu Silah Fabrikası'nda da imal edilebilmesi için 1864 yllında İngiltere’den Enfield şeşhaneli tüfek imaline mahsus makinelerin ithaline ve bunları kuracak, kullanacak ve kullanımını Osmanlı ustalarına öğretecek teknik ekibin getirtilmesine karar verildi. ${ }^{103}$ İngiltere'de yürütülen araştırmalar neticesinde makinelerin siparişi verildi. 1865 yılının başında bir kısmı İstanbul'a gelen makinelerle aynı gemide makinelerin kurulumlarını ve kullanımlarını üstlenecek 3 kişilik İngiliz teknik ekip de bulunuyordu. ${ }^{104}$ İngiliz teknisyenler 1865 yılı içinde makineleri Zeytinburnu Silah Fabrikası'ndaki yerlerine kurdular, aynı yılın sonlarında Enfield tüfeklerin imalatına başlandı. Ancak bu imalattan daha çok montaj işlemiydi. Çünkü gelen makineler arasında tüfeklerin kuyruk takımı, piston, nişangâh gibi önemli parçalarını imal edecek makine ve tezgâhlar yoktu. Dolayısıyla tüfek aksamı başta İn-

101 Soyluer, "Osmanlı Silah Sanayiinde Modernleşme Çabaları”, s. 202-203.

102 Soyluer, "Osmanlı Silah Sanayiinde Modernleşme Çabaları”, s. 204-231.

103 BOA, Hariciye Nezâreti Londra Sefâreti Belgeleri Tasnifi (HR. SFR. 3), 85-18.

104 BOA, HR. SFR. 3, 96-29. 
giltere olmak üzere Belçika, Avusturya gibi devletlerden ithal edilerek İstanbul'a getirtiliyor, Zeytinburnu Fabrikası'nda İngiliz ustalar denetiminde sadece namlulara yiv açma ve kundak imal işlemleriyle, tüfeklerin parçalarının birleştirilmesi gerçekleştiriliyordu. 1867 yılının sonlarına kadar “yerli” Enfield üretimi serüveni bu şekilde devam etti.

Osmanlı ordusunun Enfield tüfekleriyle silahlandırılması tasarısı, tüfeklerin ithali ve Zeytinburnu Silah Fabrikası'nda kısmî olarak gerçekleştirilen montajıyla bir hâl yoluna koyulmuşken, Avrupa'daki devletlerin silah teknolojileri geliştirme konusundaki rekabeti durmak bilmiyordu. İngiltere, Fransa, Belçika, Prusya, İtalya, İsveç, Avusturya ve Amerika şeşhaneli tüfekleri daha hızlı ve etkin bir şekilde kullanabilme arayışı içindeydiler. Bu maksatla pek çok çalışma yürütülmekteydi. Sonunda geçmişte çok kullanışı olmadığı gerekçesiyle terk edilen kuyruktan dolar mekanizma yeniden geliştirilmişti. Yapılan birçok denemeden sonra kolay doldurulabilen, kısa sürede çok daha fazla atış imkânı sunan, ağızdan dolar şeşhaneli tüfeklere göre daha uzun menzilli, isabet ve darbe gücü daha yüksek iğneli ateşleme düzeneğine sahip tüfekler icad edildi. Bunlar doğrudan kuyruktan dolar mekanizmalı imal edilmekle beraber, ağızdan dolar şeşhaneli tüfekler de bu tüfeklere dönüştürülebiliyordu. İlk zamanlarda silah sanayinin önde gelen devletlerinden Fransa Chassepot, İngiltere ve İtalya Snider (İngiltere kısa bir süre sonra Martini Henry tüfeklerine geçiş yaptı), Belçika Albany, İspanya ve Avusturya ise Remington marka iğneli tüfekleri kullanmışlard. ${ }^{105}$

Osmanlı Devleti'nin Avrupa'da yaşanan bu gelişmelere kayıtsız kalması elbette beklenemezdi. Sultan Abdülaziz' in (saltanatı 1861-1876), Avrupa seyahati sırasında kendisine sunulan pek çok numune arasında özellikle beğenip ilgi gösterdiği bir marka vardı. Amerikan J. Snider’ın geliştirdiği kuyruktan dolar mekanizmaya sahip bir iğneli tüfek türü olan Snider tüfekleri, sağlamlığı, değiştirilebilir mekanizması, etkin isabet gücü ve menziliyle Avrupa'da özellikle İngiliz ve İtalyan ordularınca tercih edilerek kullanılmaya ve üretilmeye başlamıştı. Osmanlı ordusunun tamamı, sultanın özelliklerini bizzat görerek hayran kaldığı kuyruktan dolar bu tüfeklerle teçhiz edilecekti. Fakat orijinal Snider'lar çok pahalı olduğundan, bunlardan çok sayıda sipariş verilmesinin uzun vadede hazineyi büyük zarara uğratacağı açıktı. Bu yüzden tıpkı İngiltere, Belçika, Avusturya, Rusya ve diğer Avrupa devletlerinde yapıldığı gibi eldeki ve ithal yolla temin edilecek Enfield ların Snider'a dönüştürülmesine karar verildi. Babıâli, 1867 Mart'ı sonunda

105 Yüzbaşı Hakkı, Esliha-yı Nariyye-i Hafife, s. 6. 
Londra Sefiri Musurus Bey’e ağızdan dolar Enfield tüfekleri, kuyruktan dolar Snider tüfeğe dönüştürmeye mahsus makinelerin temini talimatını verdi. ${ }^{106}$ Bir kısmı İngiltere'de, bir kısmı da İngiltere'de pahalı olduğu gerekçesiyle Amerika’da yaptırılan makineler, 1867 Sonbaharında İstanbul'a geldi. Makineleri kurmak ve kullanımlarını Zeytinburnu Silah Fabrikası personeline öğretmek maksadıyla başlarında ustabaşı Stevenson'ın bulunduğu 3 kişilik İngiliz teknik ekip de aynı tarihlerde İstanbul'dayd..$^{107}$

Kuyruk takımları Avrupa'dan ithal edilmek koşuluyla günde 200 adet Enfield tüfeği Snider tüfeğe dönüştüren makine ve tezgâhlar 1868 yılının başında faaliyete geçti. Zeytinburnu Silah Fabrikası'nda kurulan bu yeni sistemde istihdam edilmek üzere kuyruktan dolar tüfeklerin ateşleme tertibatı konusunda uzman İngiliz ustabaşı William Powell 1868 Şubat'ında iki yıllığına İstanbul'a gönderildi. ${ }^{108}$ Powell'1 1868 yılı sonunda Enfield Royal Small Arms Factory'den gönderilen çilingir-tüfek demircisi John Blair izledi. ${ }^{109}$ Osmanlı Devleti'ne makine ve uzman tedariki konusunda liderliği 1840’ların sonlarında Belçika ve Fransa’ya kaptırmış olan İngiltere, bu unvanını tekrar kazanmış gözüküyordu. Zeytinburnu Silah Fabrikası'nda Enfield ve Snider tüfeklerinin imal ve dönüşümlerine başlanması nedeniyle çalıştırılan personel konusunda da birtakım düzenlemelere gidildi. Yapılan işler teknik bilgi gerektirdiğinden 1862 yılından beri fabrikada vasıfsız amele çalıştırılmıyordu. Özellikle sanayi mektebi mezunu öğrencilerle sanayi-imalat alayı neferleri çalıştırılmasına ehemmiyet verildi. ${ }^{110}$ Sadece Snider'a dönüşüm işlemlerinin yapıldığ kişiye ulaşmıştı. ${ }^{111} \mathrm{Bu}$ sırada iğneliye dönüştürülen tüfek sayısını artıırmak ve tüfeklerin kuyruk takımını da imal ederek dışa bağımlılıktan tamamen kurtulmak

106 BOA, HR. SFR. 3, 122-73.

107 BOA, HR. SFR. 3, 129-53; BOA, HR. SFR. 3, 129-73; HR. SFR. 3, No.129-120; HR. SFR. 3, 130-12; HR. SFR. 3, 130-50. Dört yılı aşkın süredir Zeytinburnu Silah Fabrikası'nda Snider tüfek imalatı ve dönüşümüyle meşgul olan ustabaşı Stevenson'a hizmetlerinden ötürü 1872 yılında 4. Dereceden Mecidiye Nişanı verildi. BOA, I. DH., 45224, 15 Ra 1289 (23 Mayıs 1872) tarihli irade.

108 BOA, HR. SFR. 3, 134-69, Lef 2, 3 Şubat 1868 tarihli kontrat sûreti; BOA, HR. SFR. 3, 135-40, Lef 1, konsolos Mr. Gadban'dan Sefir Musurus Bey'e 15 Şubat 1868 tarihli mektup; BOA, MAD. d., 10584, s. 48.

109 BOA, HR. SFR. 3, 145-111, Lef 3-4.

110 BOA, I. DH., 39985, Lef 2, 28 Z 1284 (21 Nisan 1868) tarihli irade; BOA, A. MKT. MHM., 406-19, 5 M 1285 (28 Nisan 1868) tarihli sadaret tezkiresi.

111 BOA, HR. SFR. 3, 132-2, Lef 2. 
için yeni dönüşüm tezgâhlarıyla kuyruk takımı imaline mahsus makineleri temin etmek üzere İngiltere’ye yeni makineler sipariş verilmek istendiyse de yüksek maliyeti gerekçesiyle bekleme kararı alınd..$^{112}$

Ancak ordudaki Snider tüfek açı̆̆ının bir an evvel giderilmesi gerekiyordu. $\mathrm{Bu}$ nedenle 1868 yılı sonunda makine alımları yine gündeme geldi. Miralay Rüstem Bey, İngiltere ve Belçika'daki fabrikalarda fiyat araştırması yaptı. Oradan Amerika'ya geçerek buradaki makine imal fabrikalarında da incelemelerde bulunan Rüstem Bey, Babıâli'ye makinelerin Amerika'dan daha uygun fiyata alınabileceğini bildirdi. ${ }^{113}$ Makinelerin Amerika'dan teminine karar verildiği sırada Washington'dan sevindirici bir haber daha geldi. Amerika'daki birkaç büyük tüfek fabrikası iflas sebebiyle kapandığından, gayet iyi durumdaki makinelerini yarı fiyatına alma imkânı doğmuştu. Bu firsat hemen değerlendirilerek 1869 Ağustos'undan itibaren Snider tüfeklerin kuyruk takımlarını imal eden makinelerle, tüfeklerin Enfielddan Snider'a dönüşümüne mahsus tezgâh ve makinelerin Amerika'daki müflis fabrikalardan satın alınmasına başlandı. Makine ve tezgâhları kuracak yetkin bir makinistle, bunlarda çalıştırılacak yeterli sayıda kalifiye eleman gereksinimi de kapanan fabrikaların işsiz kalan makinistleri ve elemanlarından giderildi. ${ }^{114}$ Bundan sonraki yirmi yıllık süreçte Osmanlı Devleti'nin sanayisi için ihtiyaç duyduğu makinelerle gerekli teknisyen ve uzmanları teminde sıklıkla başvurduğu adres pek çok Avrupa devletinin de yaptığı gibi Amerika Birleşik Devletleri oldu. Bu makinelerin tamamının temini ve İstanbul'a getirilerek hizmete girişi 1872 yılı sonlarını buldu. Artık Zeytinburnu Silah Fabrikası, günde 200 civarında Snider tüfeğin imal edilebildiği ve 300'ün üzerinde Enfield ve Springfield $1 \mathrm{n}$ da Snider'a dönüştürülebildiği bir fabrikaydı. ${ }^{115}$

Osmanlı hafif silah üretiminde her şeyin yoluna girdiği düşünülürken, Avrupa silah teknolojilerinde meydana gelen gelişmeler bunun tersini gösteriyordu. 1872 yılında İngiltere'den getirtilen numuneleri çok beğenilerek aynı yıl Amerikàya 200.000 tane ssmarlanan ve dönemin en mükemmel iğneli tüfeği olarak nitelendirilen 1871 model Martini Henry tüfekleri, Zeytinburnu Silah

112 Bu konuda ayrıntılı bilgi için bkz. Soyluer, "Osmanlı Silah Sanayiinde Modernleşme Çabaları”, s. 239-242.

113 Soyluer, “Osmanlı Silah Sanayiinde Modernleşme Çabaları”, s. 245.

114 BOA, Hariciye Nezâreti Tercüme Odası Belgeleri Tasnifi (HR. TO.), 188-3, Washington Sefaret-i Seniyyesi'nden Hariciye Nezâreti'ne 6 Şubat 1870 tarihinde gönderilen telgraf tercümesi.

115 Soyluer, “Osmanlı Silah Sanayiinde Modernleşme Çabaları”, s. 247-248. 
Fabrikası'nda Avrupai tarzda üretim faaliyetlerinin farklı bir seyre yönelmesine neden oldu. Çünkü Osmanlı Devleti'nde iğneli tüfek imal edilebilmesi maksadıyla o ana kadar gerçekleştirilen tüm makine ve alet-edevat alımları, Snider tüfekleriyle Springfield-Peabody üretim sistemine yönelik olarak yapılmıştı. Zor ekonomik koşullarda, büyük yatırımlar karşılığında oluşturulmaya çalışılan tesiste imalatta maharet ve germiyyet sağlanıp, mevcut üretim ilave tezgâhlarla daha da genişletilecekken Avrupa'da mevcut iğneli tüfeklerin daha gelişmiş modelinin icadı mevcut üretim dengesini sarstı. Yeni iğneli tüfekler ya mamul olarak tedarik edilecek ya da imallerine yönelik makineler temin edilerek yerli üretim yeniden düzenlenecekti. Yerli üretimin Osmanlı Devleti'ne her zaman pahalıya mâl olduğu geçmişteki acı tecrübelerle sabitti. Aynı zamanda yarım milyonu aşkın tüfeğin birkaç parça makine ve tezgâh ithaliyle kısa sürede imal edilip askere dağıtılması da mümkün değildi. Vakit kaybetmemek ve mali yönden daha büyük sıkıntıya düşmemek maksadıyla ilk etapta Martini Henry tüfeklerinin mamul olarak temini cihetine gidildi. II. Abdülhamid devrine kadar da (saltanatı 1876-1909) bu tüfeklerin imaline mahsus makine ve tezgâhların ithali için teşebbüste bulunulmadı. Abdülaziz'in saltanatı sonlarında Osmanlı ordusundaki silahların büyük çoğunluğunu İngiliz ve Amerikan tüfekleri oluşturuyordu. Dolayısıyla Zeytinburnu Silah Fabrikası'nda üretimi, dönüşümü ve tamiri yapılan tüfekler de bu iki devletin geliştirdiği tüfeklerdi. Fabrikada istihdam edilen yabancı uzman ve teknisyenlerin neredeyse tamamı İngiliz ve Amerikan uyrukluydu. Belçikalı ve Fransız uzman ve teknisyenlerin yapacak pek işleri kalmadığından, kendilerine ülkelerine dönmeleri için yol verilmeye başlandı. ${ }^{116}$

1872 yilında Amerika'ya 200.000 tanesi ismarlanan Martini Henry tüfeklerinden, 1873 yılında yine Amerika’ya 300.000 tane daha sipariş verilmişti. Amaç kısa sürede tüm Osmanlı ordusuna yetecek kadar Martini Henry tüfeğe sahip olmaktı. Tüfeklerin tamamının ordulara dağıtımı 1880 yılını buldu. Sayısı bu denli fazla olan tüfekler için Tophane ve Zeytinburnu Silah Fabrikası'nda bir imalathane ve tamir atölyesinin bulunmayışı büyük eksiklikti. Ancak devletin içerisinde bulunduğu mali buhran ve silah firmalarının üretim imtiyazı konusunda çıkardıkları sorunlar, buna izin vermiyordu. Bu nedenle 1880 ’lerin başına kadar Martini Henry tüfeklerin imal ve tamirine mahsus makine ve tezgâhlardan edinilemedi. II. Abdülhamid devrinde yakalanmaya çalışılan ekonomik istikrar neticesinde

116 Zeytinburnu'ndaki Fransız ustaların son temsilcisi Cahier usta ve ekibine 1876 yılında Fransa'ya dönmesi için verilen 1560 kuruş tutarındaki harcırah, Mühimmat-1 Harbiye tahsisatından karşılanmıştı. BOA, MAD. d., 11108, s. 54. 
bir nebze olsun rahat nefes alınınca, Amerika'dan uygun fiyata satın alınan ikinci el makine ve tezgâhlarla Zeytinburnu Silah Fabrikası'nda bir bölüm oluşturuldu. Makinelerin kurulumu ve işletimi için Amerika'dan ustabaşı, usta ve teknisyenler getirtildi. Bütün bunların neticesinde 1880 'li yıllarda Zeytinburnu'nda günde 20 ila 40 arasında Martini Henry tüfeği imal ve bir o kadarı da tamir edilebiliyordu. ${ }^{117}$

Osmanlı hafif silah imalatında bu gelişmeler yaşanırken, 1882 yılında Albay Kaehler önderliğindeki Prusyalı reform subayları, Osmanlı ordusunu tamamıyla Alman ordusu örneğinde teşkilâtlandırmak için İstanbul'a geldiler. ${ }^{118} 1885$ yılında Kaehler'in ölümü üzerine yerine 1883 'ten beri Türkiye'de bulunan Von der Goltz geçmişti. 1895 yılına kadar Osmanlı ordusunda görev yapacak olan Von der Goltz’un maiyetinde çalışmak üzere Almanya’dan çok sayıda talim subayı gönderilmişti. Artık Osmanlı ordusu büyük ölçüde Alman etkisine girmişti. Prusyalı reform subayları bir taraftan orduyu yapılandırırken, diğer yandan devletlerinin onlara yüklediği misyon gereği Alman silah endüstrisinin mümessili gibi hareket ediyorlardı. Birinci Dünya Savaşı sonuna kadar sürecek Alman etkisi sonucunda Alman ağır silah endüstrisinin öncü temsilcisi Krupp firmasılla, hafif silah ve mühimmat endüstrisinin temsilcileri Mauser ve Loewe firmalarıyla büyük meblağlar karşılığında silah ve mühimmat alım anlaşmaları imzaland. ${ }^{119}$

Alman askerî heyeti üyelerinin Osmanlı ordusundaki silahların Alman ordusunda kullanılanlarla aynı olmak koşuluyla tek tipleştirilmesini rapor etmeleri üzerine Von der Goltz’un heyet başkanlığı yaptığı döneme tesadüf eden 1887 yılında Waffenfabrik Mauser firmasıyla 500.000 adet 1887 model Mauser tüfek

117 Fatih Tetik, Serdal Soyluer, "Silah İthalatı ve Kara Harp Sanayii", Osmanlı Askerî Tarihi: Kara, Deniz ve Hava Kuvvetleri, 1792-1918, ed. Gültekin Yıldız (İstanbul: Timaş Yayınları, 2013), s. 114.

118 Jehuda L. Wallach, Bir Askerî Yardımın Anatomisi: Türkiye’de Prusya-Alman Askerî Heyetleri, 1835-1919, çev. Fahri Çeliker (Ankara: Genelkurmay Harp Tarihi Başkanlığı Yayınları, 1977), s. 25-55. Kâzım Karabekir, Türkiye'de ve Türk Ordusunda Almanlar, haz. Orhan Hülagü, Ömer Hakan Özalp (İstanbul: Emre Yayınları, 2001), s. 202.

119 Bu konuda son zamanlarda yapılmış müstakil ve mufassal birkaç çalışma için bkz. Fahri Türk, Türkiye ile Almanya Arasindaki Silah Ticareti 1871-1914 (İstanbul: IQ Kültür Yayıncılık, 2012); Ali Serdar Mete, "Osmanlı İmparatorluğundan Türkiye Cumhuriyetine Türk Ordusunda Mavzer Tüfekleri“ (yüksek lisans tezi), Yeditepe Üniversitesi Atatürk İlkeleri ve İnkılap Tarihi Enstitüsü, 2012; Naci Yorulmaz, Arming the Sultan: German Arms Trade and Personal Diplomacy in the Ottoman Empire before World War I (London, New York: I.B. Tauris, 2014). 
alımına yönelik anlaşma imzalandı. ${ }^{120}$ Daha sonra aynı tüfeğin 1890 ve 1893 modellerine yönelik yapılan anlaşmalar neticesinde on dokuzuncu yüzyıl sonunda Osmanlı ordusu envanterine kayıtlı Mauser tüfek sayısı 700.000 'i aşt1. ${ }^{121} 1890$ 'ların ilk yıllarında Almanya'dan ithal edilen tezgâhlar sayesinde 1890 model Mauser tüfeklerine ait kasatura, harbi, kundak, yay, mil, piston, şarjör gibi yedek parça ve tamamlayıcı aksam imal ve tamir edilmeye başlandı. Bu tezgâhları kurmak ve kullanımlarına nezâret etmek maksadıyla Waffenfabrik Mauser firması, gerekli teknik ekibi İstanbul'a gönderdi. ${ }^{122}$

Alman İmparatoru Kaiser II. Wilhelm'in 1898 yılında İstanbul'a gerçekleştirdiği ziyareti sırasında 1893 model Mauser tüfeklerinden Osmanlı silah imalathanelerinde de üretilmesi için talimat vermesi üzerine Osmanlı Devleti hizmetindeki Alman askerî yetkilileri hemen gerekli hazırlıklara başladı. Gereksinim duyulan tezgâh ve aparatlar Waffenfabrik Mauser firmasına sipariş edildi. Tezgâh ve aparatlarla birlikte İstanbul'a gönderilecek yeterli sayıda teknisyen ve usta da temin edildi. Silah imalathanelerindeki Martini-Henry imal ve dönüşümü için kullanılmakta olan tezgâhların bir kısmı Mauser tüfek imaline uygun hale getirildi. ${ }^{123}$ Yapılan düzenlemeler neticesinde 1900'lerin başlarından itibaren 1893 model Mauser tüfeklerinden İstanbul'da da kısmî olarak üretilmeye başland. Yerli üretim Mauser'ler orijinallerin taklidi olduğundan bunlara Muaddel Mauser Tüfek adı verildi. ${ }^{124} \mathrm{~S}_{1-}$ nırlı yerli üretim ordu ihtiyacını karşılamaya asla yetmeyeceğinden ve Almanya'da Mauser'lerin 1903 ve 1905 modelleri geliştirildiğinden 1903-1911 yılları arasında Osmanlı ordusu için Waffenfabrik Mauser Firması'na 250.000 adet 1903 ve 1905 model Mauser piyade tüfeği ve karabina sipariş edildi. ${ }^{125}$

Osmanlı askerî yetkilileri Birinci Dünya Savaşı başlayınca Muaddel Mauser Tüfek imalat ve dönüşümüne etkinlik kazandırmak istemişlerdi. Ancak bunun için silah atölyelerinde müttefik Almanya’nın desteğine bağlı ciddi

120 Wallach, Bir Askerî Yardımın Anatomisi, s. 96; Türk, Türkiye ile Almanya Arasındaki Silah Ticareti, s. 189; Mete, "Osmanlı İmparatorluğundan Türkiye Cumhuriyetine”, s. 53-56.

121 Türk, Türkiye ile Almanya Arasindaki Silah Ticareti, s. 193; Mete, "Osmanlı İmparatorluğundan Türkiye Cumhuriyetine”, s. 56-59, 63.

122 Tetik, Soyluer, "Silah İthalatı ve Kara Harp Sanayii", s. 114-115.

123 Abdurrahim Aydın, Tuncay Zorlu, "Transfer of German Military Know-How and Technology to the Ottoman Military Factories at the Beginning of the First World War," Belleten LXXIX/285 (2015), s. 750-752.

124 Mete, "Osmanlı İmparatorluğundan Türkiye Cumhuriyetine”, s. 63-64, dipnot 175.

125 Mete, "Osmanlı İmparatorluğundan Türkiye Cumhuriyetine”, s. 63. 
düzenlemelere ihtiyaç vard. ${ }^{126}$ Bu kapsamda neler yapılabileceğine dair İmalat-1 Harbiye Müdürlüğü’nün fennî işler sorumlusu (science director) Mr. Behstein'a 1915 yllında bir rapor hazırlatıld. Mr. Behstein raporunda temas ettiği mevcut imalathanelerin onarımı ve yeniden yapılandırılması, imalat sahasının genişletilmesi, montaj binalarının birbirine yakın yerlere taşınması, makine ve tezgâhların modernize edilmesi, ilave tezgâhların tedariki ve montajı, gerekli teknik ekip ve personelin temini gibi koşullar sağlandığı takdirde Osmanlı tüfek imalathanelerinde günde 250 adet Mauser tüfek imalinin mümkün olacağını iddia ediyordu. ${ }^{127}$ Mr. Behstein'ın reçetesinin tatbik edilip edilmediği ve edildiyse de ne sonuç verdiği kesin olarak bilinmemektedir. Ancak gerçekleşmesi zamana, güçlü bir ekonomiye, sağlam bir teknolojik geçmiş ve alt yapıya ve bunun paralelinde çok sayıda tecrübeli teknisyenin ve çalışanın varlığına bağlı olan Behstein projesinin koşullarını yerine getirmeye Osmanlı Devleti'nin ne zamanı, ne parası, ne alt yapısı, ne de yeterli teknik ekibi vard. ${ }^{128}$ Dolayısıyla kuvvetle muhtemel bu proje hayata geçirilemedi. Birinci Dünya Savaşı boyunca müttefik iki devlet arasında yapılan antlaşmalarla Almanya'nın Osmanlı Devleti'ne silah ve mühimmat tedariki satış ve hibeler yoluyla devam etti. Alman teknisyenler ve silah ustaları Birinci Dünya Savaşı sona erinceye kadar Zeytinburnu Silah Fabrikası ve ona bağlı hafif silah imal ve tamir atölyelerinde görevlerini sürdürdü.

\section{Sonuç}

Osmanlılar muhtemelen ticaret yoluyla ya da Balkan ve Doğu Akdeniz'de Avrupalı hasımlarına karşı yapmış oldukları akın ve savaşlar neticesinde tanışmış oldukları tüfek cinsi silahı etkin bir şekilde ilk kez II. Kosova Savaşı'nda kullanmıştı. Osmanlılar bu silahı on beşinci yüzyılın sonlarına doğru ve on altıncı yüzyıl boyunca geliştirerek kendilerine özgü bir tüfek türü meydana getirmişlerdi. Osmanlı tüfeği Avrupa menşeli türlerine oranla daha hafif ve kullanışlı olduğundan Yakın ve Uzak Doğu'daki birtakım devletlerce de tercih edilmişti. Osmanlı Devleti sadece kendi ürettiği tüfekleri kullanmakla yetinmemiş, aynı zamanda Avrupa'dan savaş ganimeti olarak veya Papalığın kesin emirlerle satışını

$126 \mathrm{Bu}$ düzenlemeler hakkında ayrıntılı bilgi için bkz. Aydın, Zorlu, "Transfer of German Military Know-How and Technology", s. 750-751.

127 Behstein'ın raporunda değindiği hususlar hakkında bkz. Aydın, Zorlu, "Transfer of German Military Know-How and Technology”, s. 752-756.

128 Aydın, Zorlu, "Transfer of German Military Know-How and Technology”, s. 757. 
yasakladığı hâlde satın alma yoluyla temin ettiği tüfekleri de kullanmıştı. Bu tüfeklerin imal ve tamiri için ilk zamanlarda Topkapı Sarayı bünyesinde Cemaat-i Tüfengciyân adlı bir zanaatkâr grubu meydana getirilmişti. Tamamı İspanyol Yahudileri ve Rus uyruklulardan oluşan bu ilk tüfekçi ustası grubuna zaman içerisinde yeni fertler de katılmış ve müessese genişleyerek silahhâne, tüfekhânel tüfenghâne, tüfeng kârhanesi adı verilen tüfek imalathaneleri teşkil edilmişti. Tüfek imalatı ve tamiri yalnızca İstanbul'daki tüfekhanelerle sınırlı kalmamıştı. Devletin Şam, Mısır, Cezayir gibi Orta Doğu ve Kuzey Afrika'daki eyaletleriyle, Anadolu ve Rumeli'deki sefer güzergâhlarında bulunan önemli kalelerinde küçük çaplı silah atölyeleri mevcuttu. Ancak tüm tüfek imalathanelerinin merkezi payitaht İstanbul'daki Tüfekhane-i Âmire adı verilen tesisti. Tüfekhane-i Âmire ilkin Unkapanı'nda tüfekçi esnafına ait dükkânlardan oluşan bir yapılar topluluğundan ibaretken, sık sık vuku' bulan yangınlarda epey tahribata uğramış ve güvenlik gerekçesiyle Cibalikapı sahilinde kargir olarak inşa edilen büyük bir binaya taşınmıştı. Geleneksel teknoloji ve tekniklerle tüfek imalatının sürdürüldüğü tesis zaman içerisinde imalat tekniği konusunda kendisini geliştiremediğinden burada imal edilen tüfekler kalite bakımından özel tüfek imalathaneleri mamulü ve Avrupa menşe li tüfeklerle rekabet edemez duruma geldi. Osmanlı idarecileri bu duruma son vermek ve Avrupa ordularında kullanılmakta olan tüfeklerden imal edilebilmesi maksadıyla on sekizinci yüzyılın son çeyreğinde Avrupa'dan getirtilen tüfek ustalarına Hasköy'de ve sonra Levend Çiftliği'nde tüfek imalathaneleri kurdurdular. Ancak bu girişim on dokuzuncu yüzyıl başındaki iki isyan neticesinde akamete uğradı. İsyanlarda zarar gören Levend Çiftliği’ndeki düzenek ve yetişen ustalar, Cibalikapı'daki Tüfekhane-i Âmire'ye nakledilerek modern ve kaliteli tüfek üretimi merkez tüfekhanede sürdürülmeye çalışıldı. On dokuzuncu yüzyıl ortalarına kadar Cibalikapidaki yerinde hizmet veren müessese, buhar gücüyle Avrupa tarzı tüfek imal etmek maksadıyla İngiliz mühendisler tarafından 1830'larda Dolmabahçe'de inşa edilen büyük binaya taşındı. Avrupa'da gelişen silah teknolojilerine paralel olarak 1850'li yıllara kadar burada İngiliz, Fransız ve Belçikalı teknisyen ve ustalar kontrolünde buhar gücüyle tüfek imal edilmeye çalışıldı. Ancak 1843 yılında inşasına başlanan Dolmabahçe Sarayı'nın müştemilatının gittikçe genişlemesi neticesinde Dolmabahçe Tüfekhanesi aşamalı olarak tahliye edilerek Zeytinburnu'ndaki fabrikalar yerleşkesi içerisinde inşa edilen modern silah fabrikasına taşındı. Zaman içerisinde Avrupa'dan ithal edilen tüfek imaline mahsus makine ve tezgâhların da kurulmasıyla büyüyen Zeytinburnu Silah Fabrikası, Osmanlı Devleti sona erinceye kadar devletin en önemli silah imalathanesi olarak faaliyet gösterdi. 
Osmanlı Devleti, tüfek imalatında tıpkı diğer üretim sahalarında olduğu gibi yabancı uzman istihdam etmekte bir sakınca görmemiştir. Tespit edilebilen ilk tüfekçi ustası grubunun İspanyol Yahudileri ve Rus uyruklulardan meydana gelişi bunun en açık delilidir. Ancak silah üretim teknolojilerinde on yedinci yüzyıldan on sekizinci yüzyılın sonlarına kadar çok büyük bir değişiklik meydana gelmediğinden, Osmanlı Müslim ve Gayrimüslim unsurlarının birlikte faaliyet gösterdiği bu imalat sektöründe diğer alanlarda olduğu kadar yabancı uzman istihdamına pek gereksinim duyulmamıştır.

On sekizinci yüzyıl sonunda Avrupa ordularında yaygın olarak kullanılmaya başlayan çakmaklı ve süngülü tüfeklerden tüfekhanede de üretilmesini isteyen başta Sultan III. Selim olmak üzere diğer Osmanlı reformistleri bu maksatla söz konusu tüfeğin üretiminde mahir İspanyol ve Fransız ustaları Avrupadan getirterek Tüfekhane'de istihdam etmişlerdir. Ancak Avrupa'da buhar gücünün imalat sektörüne başarılı bir şekilde tatbiki neticesinde silah teknolojilerinde de büyük değişimler meydana gelmiştir. Yeni teknoloji ve geliştirilen üretim teknikleri sayesinde Avrupa Devletleri, sağlam, kolay kullanılabilen ve yüksek menzilli silahları imal etme konusunda birbirleriyle kıyasıya rekabete girişmişlerdi. Amaç silah sektöründe en iyi teknolojiyi geliştirip bunu ve bunun mahsulü olan silahları pazarlamaktı. Osmanlı Devleti'nin Avrupa'da yaşanan bu gelişmelerden kendisini izole etmesi mümkün değildi. Müzmin düşmanı Rusya’ya karşı ordusunu çağın gerektirdiği silahlarla donatmalıydı. Bunun yolu yeni silahları ve onu üreten teknolojiyi satın almaktan geçiyordu. Nitekim öyle de yapılmaya çalışıldı. Osmanlı Devleti on dokuzuncu yüzyılda özellikle savaşın sanayileştiği 1840'lardan itibaren Avrupa'dan yoğun bir silah ithalatına girişti. Böyle mühim bir konuda tamamen dışa bağımlılığın sakıncaları bilindiğinden yeni geliştirilen silahları satın almak yerine onu üreten teknolojiyi temin edip modern yerli silah sanayi meydana getirmek isteniyordu. Özellikle III. Selim döneminden beri üzerinde hassasiyetle durulan mesele buydu.

$\mathrm{Bu}$ nedenle Avrupa'nın silah üretim teknolojilerinde ileri devleti hangisi ise bu teknolojiyi o devletten satın almaya çalıştı. Ancak teknoloji transferinde makine ve tezgâh ithali tek başına yeterli değildi. Makine ve tezgâhları kuracak, işletecek ve yerli usta ve işçilere öğretecek uzmanlara da ihtiyaç vardı. Bu yüzden silah teknolojisi hangi ülkeden satın alındıysa o ülkeden gerekli teknisyen ve uzmanlar da getirtildi. Ancak Avrupa ve Amerika'da çok çabuk değişkenlik gösteren silah üretim teknolojileri Osmanlı Devleti'nin modern yerli imalat kurma planlarında aksamalara neden oldu. Büyük meblağlar harcanarak beş on yılda 
ancak tesis edilebilen ithal ikameci silah manifaktüründe yerli personel imalatın inceliklerini kavrayıp mevcut tezgâhlara yapılacak ilavelerle seri imalata geçilecekken, Avrupa'da yeni bir tüfek modeli geliştiriliyor ve eski teknolojiye ait sistem ve ürünleri az gelişmiş devletlere satılarak elden çıkarılıyordu. Avrupa devletlerinde imalat ve orduların silahlandırılması tamamen yeni teknoloji üzerinden yürütülüyordu. Avrupa ve Amerika'daki gelişmelere ayak uydurmaya çalışan Osmanlı Devleti, silah teknolojilerinin en son ve en güçlü ürünü hangisiyse onu temin etmeye büyük çaba sarf etti. Farklı devletlerden silah ve teknoloji temini, silahlanma ve imalatta melezlenme meydana getirirken teknoloji-malzeme uyumsuzluğu gibi büyük bir sorunu da doğurmuştu. Bu sorunu özellikle on dokuzuncu yüzyılın ikinci yarısında daha şiddetli biçimde yaşayan Osmanlı Devleti yıkılışına kadar kendine yeter, güçlü ve modern bir yerli silah sanayini tam olarak tesis edemedi. Bu yüzden sayıları milyonlarla ifade edilecek kadar silah ve mühimmatı ithal etmek mecburiyetinde kalarak askerî teknolojide Avrupa'ya bağımlılıktan bir türlü kurtulamadı. Bağımlılık, Osmanlı Devleti’ni büyük bir ekonomik dar boğaza sürükledi.

Tüfekhane-i Âmire’yi Mamur Kılmak: Osmanlı Tüfek Imalatında Avrupalı Uzmanlarm Rolü

Öz — Bu çalışma, Osmanlı Devleti’nin hafif silah üretim merkezi olarak kurulan Tüfekhane-i Âmire'de gerçekleştirilen tüfek imalatında Avrupalı uzmanların rolünü ele almaktadır. Makalede öncelikle Osmanlı ordusunda tüfek cinsi silahın ilk kez ne zaman etkin bir şekilde kullanılmaya başladığı ve bunların imal ve tamirlerinin nerelerde yapıldığı hakkında bilgi verilmektedir. Tüfeğin Osmanlı ordusunda ilk kez kullanılmaya başladığı devirden, devletin yıkılışına kadarki süreçte Osmanlı tüfekhanelerinde, özellikle Tüfekhane-i Âmire'de tüfek imalatının kimlerin denetiminde ve nasıl gerçekleştirildiğine, tüfekhanelerde istihdam edilen personel sayısına, uyruğuna ve Avrupalı uzmanların tüfek imalat sürecine etkilerine değinilmektedir. Daha sonra Osmanlı Devleti'nin merkez tüfek imalathanesi konumundaki Tüfekhane-i Âmire'yle, onun on dokuzuncu yüzyılın ikinci yarısından sonraki uzantısı olan Zeytinburnu Silah Fabrikası'nda istihdam edilen Avrupalı uzmanların, özellikle silah teknolojilerinin hızla gelişerek savaşın sanayileştiği bir devirde Osmanlı hafif silah imalatına etkileri anlatılmaktadır.

Anahtar Kelimeler: Osmanlı silah sanayi, Tüfekhane-i Âmire, Zeytinburnu Silah Fabrikası, tüfek, teknoloji transferi, Avrupalı uzman. 


\section{Kaynakça}

\section{Yayınlanmamı̧̧ Kaynaklar}

\section{Başbakanlık Osmanlı Arşivi}

A. MKT. MHM. (Sadaret Mektubî Mühimme Kalemi Evrakı Tasnifi) 13-53, 406-19, 761-13.

C. AS. (Cevdet Askerî Tasnifi) 8408, 8949, 12493, 16235, 18221, 20235, 21254, 21415 , 23360, 26375, 26528, 30714, 33333, 35276, 40789, 52251.

C. BH. (Cevdet Bahriye Tasnifi) 1941, 4929.

C. SM. (Cevdet Saray Mesalihi Tasnifi) 142.

HAT (Hatt-1 Hümâyûn Tasnifi) 1728, 8793, 8970, 29044, 29129.

HR. MKT. (Hariciye Nezâreti Mektubî Kalemi Belgeleri Tasnifi) 166-43, 317-97, 33526, 374-40, 374-82.

HR. SFR. 3 (Hariciye Nezâreti Londra Sefâreti Belgeleri Tasnifi) 85-18, 96-29, 122-73, 129-53, 129-73, 129-120, 130-12, 130-50, 134-69, 135-40, 145-111.

HR. SFR. 4 (Hariciye Nezâreti Paris Sefâreti Belgeleri Tasnifi) 48-6.

HR. TO. (Hariciye Nezâreti Tercüme Odası Belgeleri Tasnifi) 188-3.

İ. DH (İrade Dâhiliye Tasnifi) 1069, 8547, 11083, 20464, 22540, 39985, 45224.

İ. MVL. (İrade Meclis-i Vâlâ Tasnifi) 102, 3036, 8132, 10086.

MAD. d. (Maliyeden Müdevver Defterler Tasnifi) 8926, 8932, 8934, 10584, 11108.

MVL (Meclis-i Vâlâ Evrakı Tasnifi) 335-15.

\section{İstanbul Büyükşehir Belediyesi Atatürk Kitaplığı}

Hicrî 909-929 Yillarna Ait In'amat Defteri, Muallim Cevdet Yazmaları, O. 71.

Takvim-i Vekayi 4, 21, 413.

\section{İstanbul Üniversitesi Nadir Eserler Kütüphanesi (İÜKTB)}

Yüzbaşı Hakkı, Esliha-yı Nariyye-i Hafife, TY 81612, 1281 (1864).

\section{Yayınlanmış Kaynaklar}

Câbî Ömer Efendi: Câbî Târihi, I, haz. Mehmet Ali Beyhan, Ankara: Türk Tarih Kurumu Yayınları 2003.

Dallaway, James: Constantinople Ancient and Modern, London: Cadell \& Davies 1797.

Evliya Çelebi b. Derviş Mehmed Zillî: Evliya Çelebi Seyahatnâmesi, I, haz. Robert Dankoff, Seyit Ali Kahraman, Yücel Dağlı, İstanbul: Yapı Kredi Yayınları 2006. 
Grosvenor, Elizabeth Mary: Narrative of a Yacht Voyage in the Mediterranean During the Years 1840-1841, I, London: John Murray 1842.

Heuschling, Xavier: L'empire de Turquie, Bruxelles: Tarlier 1860.

Hobhouse, John Cam: A Journey Through Albania and Other Provinces of Turkey in Europe and Asia, to Constantinople During the Years 1809 and 1810, II, London: Cawthorn 1813.

Hovhannesyan, Sarkis Sarraf: Payitaht İstanbul'un Tarihçesi, çev. Elmon Hançer, İstanbul: Tarih Vakfı Yurt Yayınları 1997.

Karabekir, Kâzım: Türkiye'de ve Türk Ordusunda Almanlar, haz. Orhan Hülagü, Ömer Hakan Özalp, İstanbul: Emre Yayınları 2001.

Kavanin-i Yeniçeriyan (Yeniçeri Kanunları), haz. Tayfun Toroser, İstanbul: Türkiye İş Bankası Kültür Yayınları 2011.

Larpent, George: Turkey: Its History and Progress From the Journals and Correspondence of Sir James Porter, II, London: Hurst \& Blackett 1854.

MacFarlane, Charles: Constantinople in 1828, II, London: Saunders and Otley 1829. : Turkey and Its Destiny, II, London: John Murray 1850.

Mahmud Râif Efendi: Mahmud Râif Efendi ve Nizâm-ı Cedîd'e Dair Eseri, haz. Kemal Beydilli, İlhan Şahin, Ankara: Türk Tarih Kurumu Yayınları 2001.

Nicolay, Nicolas de: Muhteşem Süleymanin İmparatorluğunda, ed. Marie-Christine Gomez-Géraud, Stefanos Yerasimos, çev. Şirin Tekeli, Menekşe Tokay, İstanbul: Kitap Yayınevi 2014.

Olivier, Guillaume Antoine: Voyage dans l'Empire Othoman, l'Égypte et la Perse, I, Paris: Agasse 1800.

Pardoe, Miss Julia: The City of the Sultan; and Domestic Manners of the Turks, in 1836, II, London: Henry Colburn 1837.

Porter, David: Constantinople and Its Environs, I, New York: Harper \& Brothers 1835.

Reid, John: Turkey and The Turks, London: Tyas 1840.

Saint-Denys, A. Juchereau de: Révolutions de Constantinople en 1807 et 1808, II, Paris: Brissot-Thivars 1819.

Ubicini, M. Abdolonyme: Letters on Turkey, I, trans. Lady Easthope, London: John Murray 1856.

Walsh, Robert: A Residence at Constantinople, II, London: Frederick Westley and A. H. Davis 1836.

White, Charles: Three Years in Constantinople or, Domestic Manners of The Turks in 1844 , II, London: Henry Colburn 1846. 


\section{Araştırmalar}

Ágoston, Gábor: Barut, Top ve Tüfek: Osmanl Imparatorluğu’nun Askeri Gücü ve Silah Sanayisi, çev. Tanju Akad, İstanbul: Kitap Yayınevi 2006.

: “Osmanli’da Top, Tüfek ve Tabur”, Gábor Ágoston, Osmanlida Ateşli Silablar ve Askeri Devrim Tartısmaları, çev. ve yay. haz. Kahraman Şakul, İstanbul: Türkiye İş Bankası Kültür Yayınları 2017, s. 147-168.

: "Savaş Kazandıran Silahlar: Konstantiniye Kuşatmasından (1453) Mohaç Muharebesi'ne (1526) Osmanlı Ateşli Silahlarının Belirleyiciliği”, Gábor Ágoston, Osmanlida Ateşli Silahlar ve Askeri Devrim Tartışmaları, çev. ve yay. haz. Kahraman Şakul, İstanbul: Türkiye İş Bankası Kültür Yayınları 2017, s. 85-100.

Aksan, Virginia: "Breaking the Spell of the Baron de Tott: Reframing the Question of Military Reform in the Ottoman Empire, 1760-1830", The International History Review, 24 (2002), s. 253-277.

Asimov, Isaac: Bilim ve Buluşlar Tarihi, çev. Elif Topçugil, İstanbul: İmge Kitapevi 2006.

Aydın, Abdurrahim, Tuncay Zorlu: "Transfer of German Military Know-How and Technology to the Ottoman Military Factories at the Beginning of the First World War", Belleten LXXIX/285 (2015), s. 739-759.

Beydilli, Kemal: Türk Bilim ve Matbaacılık Tarihinde Mühendishâne Mühendishâne Matbaası ve Kütüphânesi (1776-1826), İstanbul: Eren Yayınc1lık 1995.

: Mühendishâne ve Üsküdar Matbaalarında Basılan Kitapların Listesi ve Bir Katalog, İstanbul: Eren Yayıncilık 1997.

Biographical Dictionary of the History of Technology, ed. Lance Day, Ian McNeil, London: Routledge 1996.

Cezar, Yavuz: “19. Yüzyılda Osmanlı Devleti’nde Yeni Teknoloji Uygulama ve Sınaî Tesis Kurma Çabalarından Örnekler,” Dünü ve Bugünüyle Toplum ve Ekonomi, 1 (Mart 1991), s. 161-186.

Chase, Kenneth: Ateşli Silahlar Tarihi, çev. Füsun Tayanç, Tunç Tayanç, İstanbul: Türkiye İş Bankası Kültür Yayınları 2008.

Demir, Uğur: Osmanlı Hizmetinde Bir Mühtedi: Humbaracı Ahmed Paşa, İstanbul: Yeditepe Yayınevi 2016.

Emecen, Feridun M.: “Askeri Dönüşüm Çağında Evliya Çelebi ve Ateşli Silahlar”, Feridun M. Emecen, Osmanlı Klasik Çă̆ında Savaş, İstanbul: Timaş Yayınları 2010, s. 87-102.

: "Ateşli Silahlar Çağı: Askeri Dönüşüm ve Osmanlı Ordusu”, Feridun M. Emecen, Osmanlı Klasik Çă̆ında Savaş, İstanbul: Timaş Yayınları 2010, s. 27-70.

Fidan, Giray: Kanuni Devrinde Çin'de Osmanl Tüfĕgi ve Osmanlılar, İstanbul: Yeditepe Yayınevi 2011. 
Giz, Adnan: “Türkiye'de İlk Buhar Makineleri,” İstanbul Sanayi Odası Dergisi, 57 (Kasım 1970), s. 6-7.

Gülersoy, Çelik: "Son 400 Yılda Tophane Semti” VIII. Türk Tarih Kongresi, Ankara 11-15 Ekim 1976, Kongreye Sunulan Bildiriler, III, Ankara: Türk Tarih Kurumu Yayınları 1983, s. $1637-1650$.

İlgürel, Mücteba: "Osmanlı İmparatorluğu’nda Ateşli Silâhların Yayılışı”, İstanbul Üniversitesi Edebiyat Fakültesi Tarih Dergisi, 32 (1979), s. 301-318.

İnalcık, Halil: "Military and Fiscal Transformation in the Ottoman Empire, 1600-1700", Archivum Ottomanicum, VI (1980), s. 283-337.

Levy, Avigdor: The Military Policy of Sultan Mahmud II 1808-1839, (Ph.D. Thesis) Cambridge, Mass.: Harvard University, 1968.

McNeill, William H.: “The Initial Industrialization of War, 1840-84”, William H. McNeill, The Pursuit of Power: Technology, Armed Force, and Society since AD 1000, Chicago: University of Chicago Press, 1982, s. 223-261.

Mete, Ali Serdar: Osmanlı Imparatorluğundan Türkiye Cumburiyetine Türk Ordusunda Mavzer Tüfekleri, (Yayımlanmamış Yüksek Lisans Tezi) İstanbul: Yeditepe Üniversitesi Atatürk İlkeleri ve İnkılap Tarihi Enstitüsü, 2012.

Murphey, Rhoads: "Osmanlıların Batı Teknolojisini Benimsemedeki Tutumları: Efrenci Teknisyenlerin Sivil ve Askerî Uygulamalardaki Rolü”, Osmanlılar ve Batı Teknolojisi: Yeni Araştırmalar Yeni Görüşler, haz. Ekmeleddin İhsanoğlu, İstanbul: İstanbul Üniversitesi Edebiyat Fakültesi Yayınları 1992, s. 7-20.

Müller-Wiener, Wolfgang: “15. 19. Yüzyılları Arasında İstanbul'da İmalathane ve Fabrikalar”, Osmanlılar ve Batı Teknolojisi: Yeni Araştırmalar Yeni Görüsler, haz. Ekmeleddin İhsanoğlu, İstanbul: İstanbul Üniversitesi Edebiyat Fakültesi Yayınları 1992, s. 53-120.

Özbaran, Salih: “Asyada ve Afrika’da Ateşli Silahların ve Askeri Teknolojinin Yayılmasında Osmanlıların Rolü”, Salih Özbaran, Yemen'den Basra'ya: Sınırdaki Osmanlı, İstanbul: Kitap Yayınevi 2004, s. 262-266.

Özden, Gani: "Osmanlı İmparatorluğu Silahlı Kuvvetlerinin Harp Sanayii Tesisleri”, Askeri Tarih Bülteni, 22 (Şubat 1987), s. 59-69.

Parry, Vernon J.: “İslâm'da Harb Sanatı”, çev. Erdoğan Merçil, Salih Özbaran, İstanbul Üniversitesi Edebiyat Fakültesi Tarih Dergisi, 28-29 (1974-1975), s. 193-218.

Sawai, Kazuaki: “Japon Teknolojisine Karşı: 16. Yüzyılda Doğu Asya'da Osmanlı Tüfeğinin Yeri”, Eskiçă̆dan Modernçă̆’a Ordular: Oluşum, Teşkilât ve İslev Sempozyumu (14-16 Mayıs 2007), ed. Feridun M. Emecen, İstanbul: Kitabevi Yayınları 2008, s. 341-354.

Shaw, Stanford J.: Eski ve Yeni Arasında Sultan III. Selim Yönetiminde Osmanlı Imparatorluğu, çev. Hür Güldü, İstanbul: Kapı Yayınları 2008. 
Soyluer, Serdal: Osmanlı Silah Sanayiinde Modernleşme Çabaları (1839-1876), (Yayımlanmamış Doktora Tezi) İstanbul: İstanbul Üniversitesi Sosyal Bilimler Enstitüsü, 2013.

Tekeli, İlhan, Selim İlkin: "The Public Works Program and The Development of Technology in the Ottoman Empire in the Second Half of the Nineteenth Century", Turcica, 28 (1996), s. 195-234.

Tetik, Fatih, Serdal Soyluer: "Silah İthalatı ve Kara Harp Sanayii”, Osmanlı Askerî Tarihi: Kara, Deniz ve Hava Kuvvetleri, 1792-1918, ed. Gültekin Yıldız, İstanbul: Timaş Yayınları 2013, s. 99-119.

Türk, Fahri: Türkiye ile Almanya Arasındaki Silah Ticareti 1871-1914, İstanbul: IQ Kültür Yayıncilık 2012.

Uzunçarşılı, İ. Hakkı: Osmanlı Devleti Teşkilâtından Kapukulu Ocakları, I, Ankara: Türk Tarih Kurumu Yayınları 1988.

: "Osmanlı Sarayı'nda Ehl-i Hıref (Sanatkârlar) Defterleri”, Belgeler, XI/15 (1986), s. 23-76.

Wallach, Jehuda L.: Bir Askerî Yardımın Anatomisi: Türkiye’de Prusya-Alman Askerî Heyetleri, 1835-1919, çev. Fahri Çeliker, Ankara: Genelkurmay Harp Tarihi Başkanlığı Yayınlar1 1977.

Yeşil, Fatih: İhtilâller Çăğnda Osmanlı Ordusu: Osmanlı Imparatorluğu'nda Sosyo Ekonomik ve Sosyo Politik Değişim Üzerine Bir İnceleme (1793-1826), İstanbul: Tarih Vakfi Yurt Yayınları 2016.

: "Kara Kuvvetlerinde Avrupalı Danışmanlar", Osmanlı Askerî Tarihi: Kara, Deniz ve Hava Kuvvetleri, 1792-1918, ed. Gültekin Yıldız, İstanbul: Timaş Yayınları 2013, s. 79-97.

: "Nizâm-1 Cedîd Ordusunda Tâlim ve Terbiye (1790-1807)", İstanbul Üniversitesi Edebiyat Fakültesi Tarih Dergisi, 52/2 (2010), s. 27-85.

Yıldız, Gültekin: Neferin Adı Yok: Zorunlu Askerliğe Geçiş Sürecinde Osmanlı Devleti’nde Siyaset, Ordu ve Toplum (1826-1839), İstanbul: Kitabevi Yayınları 2009.

Yorulmaz, Naci: Arming the Sultan: German Arms Trade and Personal Diplomacy in the Ottoman Empire before World War I, London, New York: I.B. Tauris 2014.

Zorlu, Tuncay: Osmanlı ve Modernleşme: III. Selim Dönemi Osmanlı Denizciliği, İstanbul: Timaş Yayınları 2014. 
